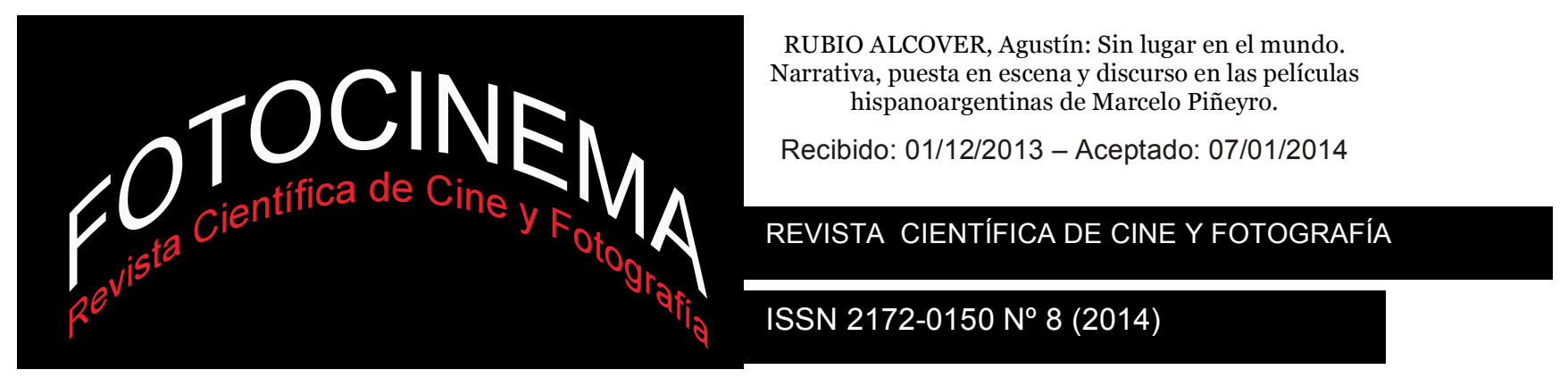

\title{
SIN LUGAR EN EL MUNDO. NARRATIVA, PUESTA EN ESCENA Y DISCURSO EN LAS PELÍCULAS HISPANOARGENTINAS DE MARCELO PIÑEYRO
}

\section{WITHOUT A PLACE IN THE WORLD. NARRATIVE, STAGING AND DISCOURSE IN FOUR HISPANIC-ARGENTINIAN FILMS BY MARCELO PIÑNERO}

\section{Resumen:}

El presente artículo aborda las cuatro películas hispanoargentinas dirigidas por Marcelo Piñeyro que se han estrenado hasta la fecha, a saber: Plata quemada (2000), Kamchatka (2002), El método (2005) y Las viudas de los jueves (2009). Y lo hace analizándolas desde la perspectiva concreta de cómo se conjuga la representación de la crisis del mundo contemporáneo en el marco de una poética propia. El artículo atiende a aspectos productivos y de recepción de los films, los compara con las obras literarias que les sirven de base (tres novelas de otros tantos novelistas: Ricardo Piglia, Marcelo Figueras y Claudia Piñeiro; y una obra de teatro, de Jordi Galceran) y se apoya en los testimonios publicados del propio director y de varios de sus colaboradores más cercanos, para ilustrar la manera en que las referencias a los conflictos de cada coyuntura (el corralito, las secuelas del 11-S, el último estallido de la economía mundial...) funcionan de manera distinta, directa o metafórica, cuando se dirigen a un público (el español) o al otro (el argentino). El estudio trata con especial detenimiento las concomitancias entre ciertas situaciones (de encierro) y en la construcción del espacio.

\author{
Agustín Rubio Alcover \\ Universitat Jaume I de Castellón (España) \\ rubioa@com.uji.es
}

\section{Palabras clave:}

Cine argentino; coproducción; autoría; narrativa; puesta en escena; adaptación; crisis; espacio fílmico

\section{Keywords:}

Argentinian Cinema; Coproduction; Authorship; Narrative; Staging; Adaptation; Crisis; Cinematic Space 
...porque las estirpes condenadas a cien años de soledad no tenían una segunda oportunidad sobre la tierra Gabriel García Márquez, Cien años de soledad

\section{Marco teórico y metodológico}

La carencia de ningún trabajo académico acerca de Marcelo Piñeyro -lo opuesto a lo que ocurre con las abundantes entrevistas que ha concedido a diversos medios de comunicación, principalmente en prensa escrita-, en contraposición con la existencia de monografías sobre otras personalidades implicadas en la producción de los films estudiados (el coproductor español de las mismas, Gerardo Herrero; el protagonista de varias de ellas, Leonardo Sbaraglia), invita a plantear su estatus como autor negligido en el panorama del cine iberoamericano contemporáneo, y más concretamente sobre un cine argentino del que parece atraer mucho más a la comunidad científica el documental más joven que la ficción -véase al respecto, por ejemplo, el dossier coordinado en el número 70 de Archivos de la Filmoteca por Laia Quílez (2012, pp. 85-91). No en vano, Alberto Elena ha situado a Piñeyro un peldaño por debajo de Adolfo Aristarain en cuanto al grado de conocimiento y aceptación de directores por parte del público español. Según él, el director de Un lugar en el mundo ha sido, sobre todo con ese film y Martín (Hache), "una suerte de buque insignia del cine argentino en España con cuya estatura ni Subiela, ni Piñeyro, ni Mignogna, ni Agresti -con ser también cineastas apreciados por el público español- podrán competir en aquellos años" (Elena, 2001, p. 43).

¿Es esa desconsideración merecida? No es nuestra intención reabrir el debate acerca de la autoría cinematográfica, sino ejercitar en relación a las cuatro películas hispanoargentinas de Marcelo Piñeyro -que recientemente ha estrenado la íntegramente española Ismael (2013) - un método de estudio del proceso de creación fílmica de mimbres convencionales pero intereses variados: a través del análisis fílmico, textual -narrativo, expresivo y discursivo- y comparado -de las obras literarias que sirven de base (tres novelas de otros tantos novelistas: Ricardo Piglia, Marcelo Figueras y Claudia Piñeiro; y una obra de teatro, de Jordi Galceran)-; centrándose en cómo se 
Agustín Rubio Alcover, Sin lugar en el mundo. Narrativa, puesta en escena y discurso en las películas hispanoargentinas de Marcelo Piñeyro

conjuga la representación de la crisis del mundo contemporáneo en el marco de una poética propia; puntuado por el dato empírico y el testimonio personal de los artífices de las películas en tanto que obras colectivas; y sin desmerecer la obviedad de que hay en la práctica cinematográfica una dimensión misteriosa, artística. El artículo atiende, así, a aspectos productivos y de recepción de los films, y se apoya en los testimonios publicados del propio director y de varios de sus colaboradores más cercanos, para llevar a cabo un ejercicio interpretativo, geopolítico por un lado y por otro sociohistórico, e ilustrar la manera en que los conflictos de cada coyuntura se codifican y apelan directa o metafóricamente según se dirijan a un público (el español) o al otro (el argentino). El propósito no difiere sustancialmente del que ya hemos ensayado en otros artículos recientes (Rubio Alcover, 2013, pp. 129-155), que suponen sendos intentos de analizar películas contemporáneas relacionando varios títulos entre sí a propósito del tratamiento (discursivo) que el cine actual hace de asuntos candentes.

\section{Marcelo Piñeyro y la "generación Ibermedia"}

Empecemos, pues, haciendo un poco de historia. Nacido en 1953 en Buenos Aires (aunque con doble nacionalidad española desde 2003), Marcelo Piñeyro se licenció en Bellas Artes de La Plata. Exsocio de Luis Puenzo con la productora Cinemanía, para quien ejerció como productor ejecutivo en el celebrado film de éste La historia oficial (1985, galardonada con el Oscar a la mejor película de habla no inglesa en la edición de 1986). Nuestro hombre debutó tras las cámaras un lustro después, con Tango feroz. La leyenda de Tanguito, una cinta “...estrenada en junio de 1993 [que] resultó una de las películas más taquilleras del cine nacional que, hasta entonces, no había hecho del rock nacional un tema con una importancia análoga a la de las óperas tangueras de los treinta y cuarenta [...] a pesar de la polémica que, en el ambiente del rock, generó la visión de Piñeyro sobre la biografía de José Alberto Iglesias Tanguito, la descendencia fue escasa” (Kohen, 2010, p. 335). Tanto esa película como sus dos siguientes, Caballos salvajes (1995) y Cenizas del paraíso (1997), fueron escritas por Aida Bortnik, autora entre 135 
Agustín Rubio Alcover, Sin lugar en el mundo. Narrativa, puesta en escena y discurso en las películas hispanoargentinas de Marcelo Piñeyro

otros del libreto de la galardonada película de Puenzo, de la adaptación de la novela de Juan José Millás La soledad era esto (Sergio Renan, 2002), y de Vientos de agua (2006), la serie de Juan José Campanella para Telecinco, ambiciosa pero cancelada. Esos tres primeros títulos no solo sirvieron a Piñeyro para consolidarse en la industria; también le influiría de manera determinante el talante de esa primera guionista habitual suya. La también porteña Aida Bortnik reconocía en una entrevista en vídeo accesible a través de Internet (Anónimo, s.f. a) su predilección sentimental e ideológica por los "antihéroes que se topan con la Historia a su pesar y la enfrentan con honor". Exiliada durante la dictadura de los coroneles, trabajó en España, Londres, Los Angeles y Nueva York; un periodo en el cual se convenció de que "el cine es una patria”. Bortnik, que consideraba que el teatro, del que procedía, era "el amor de su vida”, se reconocía admiradora de Camus y de Faulkner, se declaraba obsesionada con el mito de Sísifo, y era consciente de su deuda con el autor de La gaviota ("Trato de construir un mundo a mi manera chejoviano”).

Al filo del nuevo milenio, las expectativas personales de Piñeyro, las circunstancias políticas y los cambios industriales que estaba experimentando el cine argentino al hilo de la globalización provocaron que su trayectoria diera un giro. Con la creación del programa Ibermedia, como resultado de un acuerdo al que se llegó en la VII Cumbre Iberoamericana de Jefes de Estado y de Gobierno celebrada en 1997 en Isla Margarita (Venezuela) con la finalidad de "crear un espacio común iberoamericano en el terreno audiovisual, superando -hasta donde resulta factible- las asimetrías existentes entre las industrias de los diversos países”, un horizonte profesional nuevo se abrió para él y para sus compatriotas. España y Argentina fueron dos de las nueve naciones que, en 1998, lo constituyeron con posterioridad se fueron incorporando la práctica totalidad de los estados que integran el espacio iberoamericano-, para "fomentar la coproducción, distribución y exhibición de películas en lengua española y portuguesa, además de cubrir otros aspectos esenciales como los del desarrollo de 
Agustín Rubio Alcover, Sin lugar en el mundo. Narrativa, puesta en escena y discurso en las películas hispanoargentinas de Marcelo Piñeyro

proyectos y la formación de nuevos profesionales", desde los principios de cooperación, solidaridad y reciprocidad (Lara, 2011, p. 274).

Los productores y las empresas que han promovido los films de Marcelo Piñeyro (Óscar Kramer, Patagonik, Alquimia, Tornasol...), figuran entre las principales destinatarias de las ayudas del Programa Ibermedia (Lara, 2011, p. 279). Mientras que en Plata quemada y en Kamchatka la participación mayoritaria corría a cargo de la parte argentina, en El método y Las viudas de los jueves las empresas españolas financiaron un porcentaje mayor de la operación. El hombre de cine español más determinante para que hiciera carrera en nuestro país (o a caballo entre los dos continentes) ha sido, indudablemente, Gerardo Herrero. La relación entre ambos se remonta a Caballos salvajes, que distribuyó en España una empresa especializada propiedad del director y productor madrileño (n. 1953). Herrero había tenido la visión de que el futuro del cine español sería iberoamericano o no sería antes de que el programa Ibermedia fuera aprobado. De hecho, en abril de 1995, el futuro coproductor de las cintas que nos ocupan había escrito un artículo, titulado "Tan lejos y tan cerca", en un monográfico de Academia. Revista del cine español dedicado a "Latinoamérica, años 90". Las palabras del cineasta (productor y también director) eran premonitorias: "Resulta apasionante descubrir el interés que está despertando en nuestro país el cine latinoamericano [...] El cine español debe afrontar una doble apuesta: una mayor presencia en las pantallas de Latinoamérica, y la conformación de un régimen de coproducciones que dé continuidad al trabajo con este continente. Con la excepción de Argentina, nuestra presencia en las pantallas de Latinoamérica. La industria española debe aceptar el reto de colocar nuestras producciones en el mercado culturalmente más afín. Estoy absolutamente convencido de que tenemos un hueco y muchas posibilidades. iTodavía estamos a tiempo! [...] Brillante porvenir tendrán quienes sepan ver un poco más lejos. Estoy convencido de que tenemos un futuro común" (pp. 86-87).

Casi quince años después, Herrero había hecho realidad su sueño, y podía ufanarse ante Jara Yáñez de ser uno de los productores iberoamericanos de 
Agustín Rubio Alcover, Sin lugar en el mundo. Narrativa, puesta en escena y discurso en las películas hispanoargentinas de Marcelo Piñeyro

referencia y, de paso, ponderar su implicación como productor de cintas ajenas y valorar su relación profesional con Marcelo Piñeyro: "[Ibermedia] Es un programa pequeño, pero funciona bien, da posibilidades a películas, sobre todo latinoamericanas, para que se puedan hacer. Necesita dinero pero da resultados [...] Yo levo toda mi vida haciendo coproducciones internacionales porque, si no fuera por ellas, yo no estaría aquí en este momento: si no llega a ser porque pienso que hay dinero en otros lugares y posibilidades de ventas y coproducciones internacionales. Me gusta hacer películas españolas, pero es importante buscar otros territorios [...] Es importante entenderse con los directores. Si no hay entendimiento a nivel creativo no repito con el director, independientemente de cómo haya quedado la película. El montaje es otra parte creativa. Es un proceso que me gusta seguir de cerca. Poder argumentar, aconsejar, dar mis opiniones, discutir sobre el punto en el que se ha cortado un plano. Ahora estamos trabajando con el boceto de partitura de Las viudas de los jueves (Marcelo Piñeyro), mañana veré la película por quinta vez en esta semana. $\mathrm{Y}$ es un trabajo que disfruto porque, además, estoy muy contento con el resultado final de la película. Ayer debatimos bastante sobre una secuencia que se había caído en montaje, y que a mí me parecía necesaria desde el punto de vista narrativo. Es un trabajo muy bonito. Luego no os gustará a ninguno pero bueno...” (2009, pp. 250-251).

Por lo que a la base de las cuatro historias respecta, podría inferirse de su condición de adaptaciones que se trata de otras tantas piezas industriales, en tres de los casos directamente "de encargo" (en tanto en cuanto que, como se sabe, las citadas películas constituyen las adaptaciones de dos novelas y una obra teatral, respectivamente), por parte de uno de esos cineastas artesanales, carentes de un estilo propio o definido, que en el mejor de los casos se precian de que su sello sea la perfecta traslación a la pantalla grande de sus referentes, conforme al ideal de invisibilidad de la huella autoral. La única excepción, Kamchatka, abona a primera vista el mismo prejuicio, al tratarse de una versión desarrollada por Marcelo Figueras de la idea que, en paralelo, él mismo convirtió en la novela homónima. El hecho de que solo 
Agustín Rubio Alcover, Sin lugar en el mundo. Narrativa, puesta en escena y discurso en las películas hispanoargentinas de Marcelo Piñeyro

uno de estos largometrajes de Piñeyro no haya sido escrito por Figueras $-E l$ método, adaptación de la obra teatral de Jordi Galceran El método Gronhölm cuyo libreto compartió con el compañero de fatigas más habitual de Alejandro Amenábar (Tesis, 1995; Abre los ojos, 1997; Mar adentro, 2004; Ágora, 2009) y posterior director de éxito moderado, Mateo Gil (Nadie conoce a nadie, 1999; Blacktorn, 2011)-, puede llevar a conclusiones precipitadas.

A mayor abundamiento, las películas no guardan en principio demasiado parecido, ni argumental ni estilístico, entre sí. Plata quemada recupera un olvidado "fatto di cronaca" de la Argentina de mediados de los sesenta: la huida al Uruguay, la persecución y el acorralamiento, baño de sangre final, de una banda de ladrones, compuesta por Franco "El Nene" Brignone ("El Nene" sin más en la película: Leonardo Sbaraglia), Marcos "El Gaucho" Dorda (Ángel, de origen español, en el film: Eduardo Noriega) y Carlos "Cuervo" Merelles ("El Cuervo" en la versión audiovisual: Pablo Echarri). La acción transcurre en la convulsa Argentina del postperonismo, justo en mitad de los casi veinte años de exilio del carismático presidente. Kamchatka también acontece en un momento de crisis para el país, cuando la ausencia de Perón se dejaba sentir por razones distintas (había muerto en 1974, y las tensiones por el poder condujeron al golpe militar con que arranca la cinta). Cuenta en primera persona la historia de un niño (Matías del Pozo), hijo de un abogado (Ricardo Darín) y una científica (Cecilia Roth) militantes de izquierda, que es arrancado de su medio habitual (la residencia, el colegio, los amigos, etcétera) y obligado a forjarse otra personalidad. Bajo el alias de "Harry", inspirado en el nombre artístico de su héroe, el escapista Houdini, y de la mano de sus progenitores, de su abuelo (Héctor Alterio) y de Lucas, otro joven que vive en la clandestinidad, el protagonista se introduce en el misterio de la vida y asume la resistencia como un imperativo moral. $E l$ método representa un cambio de tercio radical: la acción transcurre en la actualidad (de su año de producción: 2005) y en España -aunque bien pudiera acontecer en cualquier otra nación del Occidente capitalista. Los protagonistas son los siete aspirantes al cargo de alto ejecutivo en la 
Agustín Rubio Alcover, Sin lugar en el mundo. Narrativa, puesta en escena y discurso en las películas hispanoargentinas de Marcelo Piñeyro

multinacional Dekia (Carlos de Arístegui Santos: Eduardo Noriega; Nieves: Najwa Nimri; Fernando: Eduard Fernández; Ricardo: Pablo Echarri; Enrique: Ernesto Alterio; Julio: Carmelo Gómez; y Ana: Adriana Ozores) que se someten al "método Grönholm”, esto es, un retorcido sistema de selección que pasa por obligar a los candidatos a competir entre sí de la manera más encarnizada. Por último, Las viudas de los jueves supone un regreso a la Argentina y al pasado, si bien al reciente (diciembre del año 2001, todavía bajo el trauma del 11 de septiembre y en la antesala del "corralito"). Narra, a través de una compleja estructura de flashbacks, el proceso que condujo a tres de los maridos más deseados de la urbanización de clase alta de Altos de la Cascada (El Tano Scaglia: Pablo Echarri; Martín Urovich: Ernesto Alterio; y Gustavo Masotta: Juan Diego Botto), a suicidarse fingiendo un accidente doméstico (al electrocutarse en la piscina por la caída del equipo musical), así como la reacción de sus respectivas esposas (Teresa: Ana Celentano; Carla: Juana Viale; y Lala: Gloria Carrá), así como de la única pareja que permanece unida (Ronie Guevara: Leonardo Sbaraglia; y Mavi: Gabriela Toscano).

Pero... Empecemos por los desenlaces y sus similitudes. Las imágenes que siguen corresponden a los planos finales de (por orden cronológico) Plata quemada [figs. 1-2], Kamchatka [fig. 3], El método [figs. 4-5] y Las viudas de los jueves [fig. 6]. En unos casos, la cámara se aleja de cuerpos que se aferran entre sí; en otros, son los personajes quienes toman distancia; en uno de ellos, dispositivo y protagonista mantienen sus posiciones mientras un vehículo en el que dos figuras tan fundamentales como sus padres se van pierden en el horizonte para siempre. Parece claro que estas similitudes, no solo iconográficas, juegan conscientemente el papel de garantizar una cierta cohesión interna, así como una acusada conciencia autoral. Mas, al tratarse de adaptaciones, ¿cómo se mantiene un mínimo equilibrio entre esta pretensión y la debida fidelidad a los textos de partida -escritos por cuatro escritores diferentes, aunque reelaborados en tres de los cuatro casos por un mismo guionista-? Si se concede el beneficio de la duda, la percepción acerca del margen de maniobra que Piñeyro se toma puede ir variando, gradual pero 
Agustín Rubio Alcover, Sin lugar en el mundo. Narrativa, puesta en escena y discurso en las películas hispanoargentinas de Marcelo Piñeyro

drásticamente, así que adentrémonos en las semejanzas y diferencias entre cada película y sus obras de referencia, así como en sus respectivos procesos de producción.

\section{Tabú e incomunicación: Plata quemada}

En 1997, cuando ya era un autor consagrado, Ricardo Piglia (Adrogué, 1940) publicó Plata quemada, que está considerada como una metanovela bastante característica de su autor. Atenta tanto a la versión que le contó en su primera juventud durante un viaje en tren una mujer tangencialmente implicada, Blanca Galeano, en unos hechos que para Piglia eran "una versión argentina de una tragedia griega" (p. 170), y escrupulosamente apegada a las noticias extraídas de la prensa de la época, la obra tiene una abierta, aunque sutil, voluntad parabólica, ya presente en el oxímoron que el título plantea entre el elemento líquido y el fuego: "Plata quemada" significa "dinero que arde", pero también el arrasamiento de los países del cono sur -de ahí que, en un momento dado, Piglia metaforice y se refiera a "la batalla del Río de la Plata" (p. 141). Los personajes están permanente, existencialmente acorralados por la necesidad de dinero, en una sociedad enferma -la cita de Bertolt Brecht bajo cuya advocación se sitúa la novela es inequívoca: “¿Qué es robar un banco comparado con fundarlo?”.

Aparte del capital argentino (Óscar Kramer y Cuatro Cabezas), la película sobre Plata quemada también cuenta con producción francesa (Mandarin) y uruguaya (Estudios Darwin). Su tramo final parece inspirado en L.A. Confidential (Curtis Hanson, 1997, a partir de la novela de James Ellroy). En el original, Piglia dedica toda la segunda mitad de la novela al acorralamiento y tiroteo de los criminales protagonistas. En el film esta escena se comprime y hace las veces de clímax; no obstante, su duración sigue estando claramente descompensada con respecto al resto de la trama, jalonada por prolongadas elipsis, lo que la aleja de los cánones del género. También es fácil reconocer la influencia estética de una cinta de Wong Kar-wai entonces reciente, Happy 
Agustín Rubio Alcover, Sin lugar en el mundo. Narrativa, puesta en escena y discurso en las películas hispanoargentinas de Marcelo Piñeyro

Together (1997), que mostraba el tedio vital de una pareja hongkonesa homosexual desplazada a Latinoamérica.

Fue el productor Oscar Kramer quien propuso a Piñeyro el proyecto y, por tanto, con quien arranca esta historia. Piglia se mostró de entrada muy reticente: "Casi te diría que Plata Quemada me eligió. Había leído la novela como quien lee una novela simplemente. Soy bastante lector pero no soy un tipo de buscar películas en lo que lee. Estaba trabajando en otro proyecto, recién terminaba de filmar Cenizas del Paraíso, y la novela me gustó, sobre todo cómo Piglia construía el relato, esta cosa de meter fuentes objetivas por todos lados y que todo tenga una fuente cierta documentada para hablar del alma de los tipos. Pero la verdad nada más, me gustó y punto. Había pasado un mes, me llama Oscar Kramer y me dice que tiene los derechos y que le interesaba hacer la película. Yo le dije que había leído el libro y que no me sentía el director para esa película. Además estaba trabajando en otro proyecto. Así que tuvimos una larga charla en la que le expliqué por qué no me sentía el indicado para hacerla. En realidad no fue un tema que reflexioné siquiera seriamente; no me despertó ninguna duda. Pero el destino se mete en la vida de uno, fui al Festival de La Habana, cargué libros, como siempre, cargué Plata Quemada, a la vuelta tenía una escala de 45 minutos en Caracas, que se transformaron en 12 horas, tenía en el bolso de mano una novela que estaba leyendo, un par de revistas y Plata quemada. Terminé la novela que estaba leyendo, de las revistas leí hasta la publicidad, y ya no sabía qué hacer, estaba encerrado en un salón y me puse a releerla. Desde la primera página me dije 'sos un pelotudo, cómo no viste esto...' y ahí me di cuenta que había tenido una lectura muy superficial de la novela. Había quedado en los mecanismos constructivos, en la trama y no había visto los personajes que tenía. $\mathrm{Y}$ eso me puso en marcha: me moría por hacer la película, por llegar a Buenos Aires y poder hablar con Kramer. En efecto, lo llamé a las 7.15 de la mañana, pobre hombre, y le dije: mirá, Oscar, ¿̇os arreglaste con alguien? Y me dice: no, no, te estaba esperando. Yo tenía una idea muy concreta de la película que quería hacer, y primero quería tener una charla con Ricardo Piglia. Si él tenía problemas con lo que yo quería hacer, 
Agustín Rubio Alcover, Sin lugar en el mundo. Narrativa, puesta en escena y discurso en las películas hispanoargentinas de Marcelo Piñeyro

me abría del proyecto. Tuve esa reunión con Piglia al día siguiente y le conté qué película quería hacer, y otra cosa que para mí era condición: no quería que trabajara él conmigo, cuando yo sé que él trabaja en guiones de cine. Él estuvo totalmente de acuerdo en ambas cosas y entonces a partir de ahí fuimos para adelante” (Anónimo, s.f. b).

El emparejamiento artístico de Piñeyro con el guionista bonaerense Marcelo Figueras (n. 1962), resultaría asimismo decisivo tanto para el feliz resultado de Plata quemada como para el futuro de ambos -si bien aparte de sus trabajos junto al director argentino, Figueras ha escrito otros éxitos del reciente cine iberoamericano como la colombiana Rosario Tijeras (Emilio Maillé, 2005), Peligrosa obsesión (Raúl Rodríguez Peila, 2008) o la hispanoargentina iAtraco! (Eduard Cortés, 2012), y ejerce también de periodista (Clarín, Humor, El Periodista, Fierro, Caín) y novelista (El espía del tiempo, 2002; la novelización homónima de la película Kamchatka, 2003; La batalla del calentamiento, 2006; Aquarium, 2009). Pero el proceso no resultaría un camino de rosas, y de ahí que el director se decidiera a buscar otros caladeros, en particular el español, en lo sucesivo: aunque el corralito tardaría aún un año en ser declarado, Plata quemada coincidió con una época difícil para el cine argentino. Según el propio Leonardo Sbaraglia, el proyecto había llegado a buen puerto casi de milagro (TOLENTINO, 2005, p. 78), y él, que se había comprometido con Juan Carlos Fresnadillo para hacer Intacto (2001) -y por eso no había podido rodar como en principio tenía intención de hacer Nueve reinas (2000)-, aprovechó también que se le abrían las puertas del cine español para afianzarse en él, mientras el panorama se despejaba en su país de origen. Para Sbaraglia, "Con Marcelo tuvimos la posibilidad de crecer mucho juntos a lo largo de casi los 10 años y cuatro películas que compartimos. Nos dimos la oportunidad de soñar con que cualquier personaje era posible. Para mí esto significó un desarrollo y una confianza en el trabajo en equipo, donde siempre existía el entusiasmo del riesgo" (Tolentino, 2005, p. 77). El intérprete había participado en las primeras películas de nuestro hombre junto a su primera pareja sentimental, la también reconocida actriz argentina Cecilia Dopazo, protagonista del 
Agustín Rubio Alcover, Sin lugar en el mundo. Narrativa, puesta en escena y discurso en las películas hispanoargentinas de Marcelo Piñeyro

debut tras la cámara de Piñeyro. Estas palabras fueron pronunciadas un lustro antes de Las viudas de los jueves, trabajo de madurez de ambos con el que reafirmaban su mutua confianza y su sintonía personal.

Del mismo modo que la condición de extranjero (gallego, por más señas) de uno de los dos protagonistas, Ángel, se formula ya en su presentación (“Ángel ni siquiera era de acá", dice la voz over), se diría que la película tematiza ese vaivén desde su mismo arranque. La presentación de los personajes ya formula, verbal y audiovisualmente, la dialéctica unicidad/dualidad, compenetración/enfrentamiento, de los componentes de cualquier pareja. Mientras la voz over -que reescribe, con información ampliada, el fragmento correspondiente de la novela de Piglia- comenta que a los protagonistas, $E l$ Nene (Leonardo Sbaraglia) y Ángel (Eduardo Noriega) "les decían los Mellizos porque eran inseparables, aunque no eran hermanos, ni siquiera eran parecidos...", la imagen los muestra, primero, por separado, en un cuarto, uno durmiendo en la cama y el otro haciendo flexiones en el suelo en más que probable alusión a sus bien discriminados roles sexuales, correlativos de sus respectivos caracteres [figs. 7-8]. Luego la cámara los muestra ya compartiendo plano -caminando muy juntos en el centro del encuadre-, y vuelve a mostrarlos de manera individual mientras la voz los describe y cuenta los orígenes, para remontarse al momento en que se conocieron en los retretes de una estación [figs. 9-10]. Sus rictus y la parquedad, casi despectiva, de las frases que se dirigen, en su primera conversación, inducen a pensar en un duelo, en parte físico y en parte psicológico, desde que el primero se enciende un cigarrillo hasta que el otro se o quita y lo estruja [figs. 11-13]: es un instante clave, en el que entre ellos se forja un vínculo indisoluble, para bien y para mal, en el que los personajes son semiconscientes de que las actitudes que mantengan (si aguantan el tipo) van a sentar un precedente en su relación: quién domina (y como tal asume una responsabilidad y un sentimiento de culpa) y quién es dominado (y en virtud de su condición de víctima posee la prerrogativa de chantajear emocionalmente al otro). Por fin, los dos últimos planos de la secuencia los muestra en la cama, desnudos y con los cuerpos entrelazados en posición 
Agustín Rubio Alcover, Sin lugar en el mundo. Narrativa, puesta en escena y discurso en las películas hispanoargentinas de Marcelo Piñeyro

fetal, mientras suena un tango que sanciona la argentinidad del tono del relato [fig. 14].

El segundo acto, "Las voces", arranca con la voz over de Ángel, que reniega de Buenos Aires. Al decir de ella que es "peor que Bilbao, peor que Marsella", se delata en cuanto a su ciudad de nacimiento y a aquella otra en la que, presumiblemente, se decantó por la delincuencia organizada. La imagen recorre su cuerpo herido de arriba abajo, desde un primer plano, hasta que prácticamente en su regazo se topa con El Nene, justo cuando Ángel afirma que "lo desea" y "lo quiere salvar" [figs. 15-16]. Otra vez, pues, el ambiguo lazo, casi enfermizo, que los une, es traspuesto por medios cinematográficos. Van en un barco pesquero, camino a Uruguay. Es de noche. Cuando Ángel regaña al Nene por fumar a bordo, porque siguiendo las brasas "las ánimas te siguen", el otro le replica descreído si éstas saben nadar. "Flotan. Son más livianas que el agua. Y brillan. Por eso te siguen. Se creen que eres una de ellas". La presencia simbólica del agua, como elemento purificador, se complica así en Plata quemada, puesto que el fuego ejerce la misma función -de ahí el desenlace, transgresor y catártico a un tiempo. En la escena siguiente desembarcan, en un amanecer azulado [fig. 17]. Ángel se pelea con El Cuervo, que, dirigiéndose a él como "gallego", lo llama "puto" (homosexual). Lo golpea, creyendo que le ha llamado "retrasado infeliz". Cuando se dan cuenta de que ha sido un malentendido, todos ríen, como si ese calificativo no fuese un insulto, sino un término neutro, absolutamente inocuo [figs. 18-20].

Con una canción de jazz como fondo, un montaje-secuencia los muestra matando el tiempo en el apartamento ("Esperar. La mayor parte del tiempo hay que esperar. Esperar al momento del atraco. Esperar para que se te vaya la fiebre. Esperar para buscarte. Esperar para mover la plata. El tiempo es algo agotador, una batalla perdida. Como en la cárcel, te preguntás como llenar el tiempo. Con el cuerpo no contás. No podés coger, no podés llorar. Te vigilan, te están encima. Te queda la cabeza nomás. Y pensás. Boludeces, pero pensás"): fumando tirados en el sofá, limpiando sus armas, bebiendo, paseando por la habitación cuando la televisión ya solo muestra la carta de 
Agustín Rubio Alcover, Sin lugar en el mundo. Narrativa, puesta en escena y discurso en las películas hispanoargentinas de Marcelo Piñeyro

ajuste, fisgoneando por la ventana, ensimismados, leyendo, espiándose unos a otros, comiendo, peleándose... También masturbándose o buscando el cuerpo de otro infructuosamente, a destiempo, cuando aquél ya ha saciado su necesidad y dormita [figs. 21-22]. Más que de los inconvenientes de una situación concreta, o de los de la vida criminal, el segmento tiene una dimensión existencial, esto es, plantea que las alianzas y las querellas, así como el hecho mismo de actuar en un momento dado, no son sino estrategias de autodefensa, para entretener (o matar) el tiempo. El Nene, Ángel y todos los demás delinquen y con ello se aíslan, paradójica, irónicamente por un afán de trascendencia; tratando de rehuir la soledad. De ahí que las imágenes finales de la película, que muestran el último suspiro de El Nene herido en brazos de su amante, y eliden el ametrallamiento de Ángel mediante un fundido a negro tras una serie de planos en los que aparecen componiendo una pietà que ni siquiera el alejamiento de la cámara rompe, supone una suerte de acto de misericordia. Piñeyro remata la película de manera muy similar a Piglia, con un rótulo (en la novela es un capítulo) que contextualiza la acción, y que reza: "Esta historia es real. Sucedió en Buenos Aires y Montevideo entre el 28 de septiembre y el 4 de noviembre de 1965. Sólo se han cambiado los nombres y algunas circunstancias".

Plata quemada se estrenó en Argentina el 1 de septiembre de 2000, un día en que las páginas de sociedad del diario Clarín daban cuenta de un caso que trazaba un sombrío paralelismo con el argumento de la flamante película de Marcelo Piñeyro: se investigaba a un centenar de policías que habían participado en un tiroteo tras el asalto a un banco, con el resultado de cuatro muertos, tres delincuentes y un sargento. Distinguido con el Premio Goya en la categoría de mejor película extranjera de habla hispana, en el año 2001, el film fue, de hecho, el detonante de un boom del cine hispanoargentino de género; eminentemente sudamericano desde el punto de vista de temas y ambientes, pero jurídicamente mestizo. Títulos como Nueve reinas y El aura (2005) del malogrado Fabián Bielinsky, El secreto de sus ojos de Juan José Campanella (tras los éxitos de las románticas El hijo de la novia (2001), El mismo amor, la misma lluvia (1999, relanzado tras el éxito de la anterior) y 
Agustín Rubio Alcover, Sin lugar en el mundo. Narrativa, puesta en escena y discurso en las películas hispanoargentinas de Marcelo Piñeyro

Luna de Avellaneda (2004), La señal (2007, codirigida con Martín Hodara por el protagonista de todos los films anteriores, Ricardo Darín, a partir de un guión del finado Eduardo Mignogna), Sin retorno de Miguel Cohan (2010), Todos tenemos un plan (2012), Tesis sobre un homicidio (2013)... El filón haría que directores españoles, como el citado Gerardo Herrero ( $E l$ corredor nocturno, 2009), Eduard Cortés (con la citada iAtraco!) o Agustí Villaronga (con la miniserie para TVE Carta a Eva, 2012) se animaran a hacer las Américas con tramas planteadas a caballo entre ambos continentes.

\section{La llamada de la sangre: Kamchatka}

Según Figueras, "La idea [de Kamchatka] surgió cuando buscaba un guión para el director de cine Marcelo Piñeyro. Ya habíamos trabajado juntos en la adaptación de Plata quemada, y estábamos ansiosos - al menos yo lo estabapor repetir la experiencia. Durante meses barajamos miles de argumentos posibles, uno de los cuales rozaba lo que terminaría siendo Kamchatka. Trataba de un niño de diez años, hijo de desaparecidos, que en la Argentina de la dictadura militar se veía obligado a vivir con su abuelo, un virtual desconocido [...] Con el tiempo descubrimos que la veta más rica estaba en lo que precedía al encuentro con el abuelo, cuando el protagonista, arrastrado por sus padres, se veía obligado a vivir la experiencia de la clandestinidad [...] Contar la historia de la clandestinidad, pues, nos permitía apartarnos del relato de horror, porque el niño sufriría la pérdida, sí (perdería su casa, su colegio, sus amigos, sus juguetes), pero al mismo tiempo aprovecharía la oportunidad para la aventura [...] Quise poner la historia en unas cuantas páginas, para trazar el mapa sobre el que avanzaría el guión. Empecé varias veces. Arrancaba con un relato en tercera persona [...] y a los pocos reglones, el relato viraba automáticamente a la primera persona y me descubría escribiendo como si el niño fuese yo [...] Había descubierto la voz de Harry. Y con ella descubrí que Kamchatka era para mí mucho más que un guión. En estado febril, le dije a Piñeyro que no sabía si Kamchatka terminaría siendo o no una película, pero que de cualquier forma yo quería escribir la novela. Me dio su beneplácito. Le entregué el cuento de sesenta páginas en que ya se 147 
Agustín Rubio Alcover, Sin lugar en el mundo. Narrativa, puesta en escena y discurso en las películas hispanoargentinas de Marcelo Piñeyro

había convertido mi sinopsis original [...] No sólo me dijo que en efecto, esa era la película que quería hacer, sino que me alentó para que escribiese el guión yo solo" (pp. 383-385).

En abierto contraste con Piglia, el guionista y narrador no hace metanovela, y abomina de la postmodernidad (“...me sublevan los que dicen que todas las historias ya han sido contadas, condenando el acto de la creación a ser la mera repetición de algo que otro ya ha hecho antes y mejor, o a trabajar en las entrelíneas, con las sobras de su banquete. Es un pensamiento tan reaccionario como decir que todas las vidas ya han sido vividas, lo cual nos convierte en hombres de segunda, imitadores de vidas prestadas, nos quita el mérito y la esperanza y vuelve inútiles nuestras pasiones. Nuestras vidas no son menores que otras vidas"; p. 342). Figueras potencia en la novela el valor simbólico del agua antes aludido, como correlato de la condición de los seres humanos: "Seguimos siendo criaturas imprecisas, como lábil era la línea de lodo de la costa. Seguimos siendo criaturas de barro, el soplo divino todavía fresco en las mejillas. Seguimos siendo anfibios, deseando el agua cuando estamos en tierra y deseando la tierra mientras nadamos en el agua oscura" (p. 79). Este motivo tiene otro desarrollo, en el marco de una obra de estructura alegórica: el protagonista, Harry, y su hermano menor, "el Enano", tratan de evitar que en la piscina del chalet ("la quinta") donde se refugian unos sapos encuentren la muerte, al arrojarse al agua y no poder salir. El ahogamiento de los inconscientes anfibios se convierte en metáfora de que la reclusión a que la familia se ha sometido, forzada por las circunstancias, provoque su aniquilación. De ahí el empeño del niño protagonista por evitar esas muertes, al verse reflejado como en una suerte de premonición; de ahí, también, el símil entre la resistencia pasiva de los disidentes de la dictadura argentina con la peninsularidad de Kamchatka. Otra de las metáforas que utiliza el novelista a modo de leitmotiv es el de la posesión de una guarida por parte de los superhéroes -por parte, en concreto, de Superman: la denominada "Fortaleza de la Soledad"-, un lugar a la vez de refugio y de reclusión, por cuanto tiene de cárcel a la que se condena uno mismo por miedo, con un valor, por tanto, ambivalente. 
Agustín Rubio Alcover, Sin lugar en el mundo. Narrativa, puesta en escena y discurso en las películas hispanoargentinas de Marcelo Piñeyro

Tanto la novela como la versión cinematográfica ponen rostro a la tragedia de los desaparecidos de la dictadura de Videla -si bien el autor del guión y la novela homónima, escrita en paralelo, hace un retruécano (“...me gusta pensar que esta es una historia de aparecidos"; p. 376). El prólogo consiste en un montaje simbólico con multiplicidad de recursos (fundidos, ralentíes...), a partir de las imágenes (subjetivas) de Harry en un instante fundamental de su vida -no en vano, la que tiene lugar en el desenlace, y donde el padre pronuncia la palabra que da nombre a la película y que resume toda una filosofía vital-: el momento en que se separa de sus padres, a los que no volverá a ver nunca. Entre otras imágenes, figuran las de la partenogénesis (conciencia representacional: el relato arranca con el comienzo de la vida, esto es, tanto la concepción de Harry como el inicio de la existencia en la noche de los tiempos: “Al principio había una célula y nada más. Esa célula se dividió en dos, y esas dos en otras, y así. De algunas células salieron los vegetales, de otras los bichos, de otras los animales y de otras nosotros. Lo que nunca explican es lo que pasa después, en el momento en que las células se convierten en una persona y el momento en que esa persona sube el Himalaya, inventa una vacuna o se vuelve un escapista famoso, como Houdini. Eso sí que es un misterio. Ningún manual habla de esas cosas, ningún maestro. Pero mi papá si me habló, una vez, la última vez que lo vi. Mi historia empieza con una célula, como todas, pero termina en Kamchatka”). Las células se convierten en el sol (en el horizonte, desde el mismo punto de la carretera en que, lo sabremos al final, el protagonista se despidió de sus padres), al cabo de varios planos la luz de un proyector cinematográfico se transforma en el sol del tablero del T.E.G., una brújula real en la dibujada en ese mismo mapa, junto a Kamchatka [figs. 23-30]. Ello implica la idea de la identidad de todos los seres vivos (y la condición inseparable de todo aquello que comparte un origen, aunque sea remoto y a pesar de lo inevitable de la muerte), e identifica los niveles microscópico y macroscópico (personas y continentes, respectivamente, separados entre sí de forma inevitable y sin embargo unidos: la partenogénesis que rima con la separación de los continentes a partir de la Pangea, y ambas con la dolorosa 
Agustín Rubio Alcover, Sin lugar en el mundo. Narrativa, puesta en escena y discurso en las películas hispanoargentinas de Marcelo Piñeyro

certidumbre de que la vida tiene un fondo poético real: como las células, los seres humanos tenemos nos reproducimos y alumbramos otros individuos distintos, de manera que cuando morimos algo de lo que fuimos permanece. Somos, pues, herederos involuntarios de quienes nos precedieron, como lo serán quienes nos sucedan.

La acción arranca con un rótulo contextualizador: "Otoño de 1976 / días después del golpe militar”. Como en Plata quemada, tanto el montage como el parlamento que lo acompaña no ocultan en Kamchatka sus ínfulas de trascendencia -de hecho, el relato arranca, inmediatamente, con la justificación de ese principio tan maximalista del prólogo, con la célula: corresponde a un documental didáctico de ciencias naturales ("La vida, el misterio supremo...”, declama la característica voz over) que el niño está viendo en la escuela.

Las ilustraciones del libro en el que descubre al personaje inciden en la capacidad del escapista para rehuir la muerte en las circunstancias más adversas -dos de ellas bajo el agua [figs. 31-32]-, y una tercera en la que, desde el punto de vista del niño, que levanta la vista del libro, se traza un paralelismo entre el célebre escapista y su propio padre [figs. 33-34]. En la adaptación cinematográfica, los padres aparecen reiteradamente reencuadrados en interiores que los atrapan (el cuarto del piso ajeno en el que pernoctan tras su primera fuga; el coche; ella, tras un ventanuco de la quinta; él, en la cabina de teléfonos; los dos, tras el parabrisas, en la escena del desenlace) [figs. 35-39]. También aquí el suicidio de los sapos en la pileta [figs. 40-41], relacionado en la mente del protagonista con la posibilidad de redimir a sus padres, empuja a Harry a obsesionarse con imitar a Houdini en quien se inspira su alias. La primera vez que padre e hijo juegan al T.E.G., un vínculo intersecuencial califica la competencia entre padre e hijo como un duelo de egos. La dialéctica entre amistad/enemistad-rivalidad, familiaridad/extrañeza-traición, se formula también en el momento en que la llamada de Harry a su amigo del colegio, Bertuccio (contraviniendo la prohibición de su madre, como medida de precaución), concluye abruptamente porque el niño cuelga, da paso a la visión de Lucas, el único 
Agustín Rubio Alcover, Sin lugar en el mundo. Narrativa, puesta en escena y discurso en las películas hispanoargentinas de Marcelo Piñeyro

nuevo amigo que hace el protagonista (un correligionario que se refugia con la familia), observándolo con gesto impenetrable, que puede representar censura o mala intención -cosa que corrobora en apariencia y desmiente la siguiente imagen: Lucas atando las manos del niño a la espalda no para castigarlo o hacerlo preso, sino para ayudarlo a aprender técnicas de escape. La idea del cariño como cárcel cristaliza así poéticamente [figs. 42-44].

En una escena que no figura en la novela, pero de la que sale una de las estampas emblemáticas de la película (el padre y el hijo en la finca de los abuelos paternos, lanzando piedras al agua), la imposibilidad de escapar, con el elemento líquido como obstáculo físico, está formulada expresamente: el niño intenta hacer una fotografía al padre, que se resiste; cuando Harry pregunta por qué no se quedan allí, su progenitor, emocionado, le pide que lo mire a los ojos (él se resiste, parapetado tras la cámara), y emplea todas sus dotes de persuasión para explicarle que es imposible [figs. 45-48]. Se trata de una secuencia harto misteriosa, que invita a preguntarse por su inclusión, en la medida en que es la única modificación que introduce Piñeyro. Para mí, la escena representa el momento en que el hijo afronta, frente a su padre, el miedo a la pérdida, y recibe de éste una respuesta desoladora, que le confirma sus peores presagios y lo obliga a madurar: el impulso de fotografiar al padre no consiste tanto en un gesto infantil (ni corresponde a una afición artística), sino un síntoma de su necesidad (diferida, por pudor) de detener el tiempo para salvar a la persona amada, a la que sabe el peligro. El niño no quiere tanto quedarse en la casa de los abuelos como prolongar el orden en que ha vivido hasta la fecha; no desea tanto tomar una instantánea del padre para poseerla y recordarlo tal y como era, cuanto evitar que el padre se salga del encuadre, se aleje de él y desaparezca. De ahí que el efecto borroso del último instante invite a ser leído tanto como un indicio de que las lágrimas le nublan la vista como que el movimiento de las cosas (el fluir del tiempo) le impide fijar la mirada. La similitud del entorno campestre en que se desarrolla esa escena de "captura" (simbólica) de la imagen del padre con una apenas anterior en la que Harry se topa con un ave atrapada en una verja y malherida, y el corte a su hermano pequeño (“El Enano”), enjabonado por 
Agustín Rubio Alcover, Sin lugar en el mundo. Narrativa, puesta en escena y discurso en las películas hispanoargentinas de Marcelo Piñeyro

su abuela [figs. 49-50], adelanta cuál va a ser el destino de la familia: ser, como dice el refrán, cazados como conejos. Ese juego de alusión/elusión es coherente con la intención del guionista: en un artículo de Manuel A. Vázquez Medel (2008, p. 51), se cita una declaración de Marcelo Figueras según la cual "Se trataba de verlo todo a través de los ojos del niño: no ver más de lo que ve, ni saber más de lo que sabe. El horror quedaba condenado, así, al fuera de cuadro. Lo intuiríamos, lo oleríamos, hasta padeceríamos sus consecuencias, pero no lo veríamos jamás”. El anterior cuadro vacío, por tanto, no es tanto, valga el pleonasmo, un pillow-shot vacío (como tampoco lo son los que se suceden tras la escapada final de la familia de la quinta [figs. 51-54], que enfocan el rastro que dejaron a su paso; las pruebas de que allí estuvieron: elementos incriminatorios para sus perseguidores, testimonios para quienes ansían reparación, justicia), como un reflejo de la turbulencia interior, de la incapacidad de dotar de sentido a las cosas a falta de aquello que permite enfocarlas y ponerlas en perspectiva: referencias, afectos, valores, personas.

La última imagen se acompaña de la voz over del protagonista infantil (poéticamente incongruente, por cierto: es infantil, si bien se supone que habla desde un presente postdictatorial, esto es, debiera corresponder a un adulto), que dice: "La última vez que lo vi, mi papá me habló de Kamchatka, y esa vez entendí. Y cada vez que jugué, papá estaba conmigo. Y cuando el partido vino malo, me quedé con él y sobreviví. Porque Kamchatka es el lugar donde resistir".

Kamchatka puede considerarse, en gran medida, una película más que representativa detonante de los cambios legislativos que llevaron a la puesta en marcha de una política de recuperación de la memoria histórica en Argentina: "Será en este contexto y a partir de la gestión presidencial de Néstor Kirchner, cuando en materia jurídica se reordenen los lineamientos referidos a crímenes de lesa humanidad. Con la Ley 25.779 el Congreso Nacional derogó en 2003 las normas de impunidad, en tanto que un fallo de la Corte Suprema de Justicia librado en junio de 2005 declaró inconstitucionales las leyes 23.492 (Punto Final) y 23.521 (Obediencia 
Debida). De este modo, el reclamado juicio y castigo a los culpables del genocidio -durante años desatendido por diversas gestiones de gobiernoqueda encausado dentro de un marco institucional” (Campodónico, 2010, p. 426). A pesar de ser predominantemente argentina, la cinta cosechó un considerable éxito en nuestro país, con más de seiscientos mil espectadores en sala, lo cual, entre 1965 y 2009, la situaba en el decimoséptimo lugar en el ranking de films argentinos o coproducidos con ese país más vistos de dicho periodo (Elena, 2011, p. 49). Los factores que lo explican son su calidad, el sentimiento de hermandad existente entre ambos países, su distribución como película nacional (en régimen de coproducción), más una cualidad intrínseca: su apelación tanto a valores universales como a unos referentes culturales y políticos específicamente iberoamericanos con una especial capacidad de interlocución entre las generaciones maduras, las que vivieron el ocaso de la dictadura franquista y asistieron a los pronunciamientos militares en el cono sur en los años setenta. No es casual que los créditos finales vayan acompañados por una versión de Palabras para Julia, el poema de José Agustín Goytisolo que causó furor en su momento cantada por Paco Ibáñez. Los versos "un hombre solo, una mujer / así, tomados de uno en uno, / son como polvo, no son nada", aquí entonados por Liliana Herrero con arreglos de Fito Páez (entonces pareja de Cecilia Roth), conducen el discurso de la película a una nueva dimensión emotiva e ideológica.

\section{Los discursos de El método (Grönholm o no Grönholm, he ahí la cuestión)}

A mediados de la década pasada, la degeneración político-económica del país y de su industria cinematográfica convenció a Piñeyro a saltar el charco. Con ello contradecía un principio por el que se había regido durante décadas: "Alguna vez dijo que prefería quedarse filmando historias que sucediesen en la puerta de su casa, antes que irse a filmar afuera, pero terminó viviendo un año y medio en España para hacer El método" (Pérez, 2005). Por aquel entonces, triunfaba en España una obra teatral escrita originalmente en 153 
Agustín Rubio Alcover, Sin lugar en el mundo. Narrativa, puesta en escena y discurso en las películas hispanoargentinas de Marcelo Piñeyro

catalán, estrenada en Barcelona y rápidamente versionada en español en una traducción de su propio autor, Jordi Galceran (Barcelona, 1964). Según parece, Piñeyro tuvo acceso a la obra de Jordi Galceran antes de que se representara por primera vez. Así se cuenta in extenso en la entrevista recién aludida, donde el propio director afirmaba que había querido captar con esta película "una polaroid del mundo de hoy": "A primera vista, entonces, El método sería entonces la primera película por encargo de Marcelo Piñeyro, puesto a adaptar una exitosa obra de teatro al cine. Pero nada más lejano a la realidad. 'Primero, porque cuando yo leí la obra de teatro aún no se había estrenado, así que no era exitosa ni nada', explica el director. 'Y en lo que respecta a mi filmografía, te diría que la única película que podríamos llamar de encargo es Plata quemada, ya que fue un proyecto que no nació de mí, sino que fue propuesto por un productor. Eso sólo en las formas, porque no la considero para nada una película de encargo"”.

Apenas terminó de leer la obra, Piñeyro se dio cuenta de que el tema le interesaba, pero no el texto en sí. Y -siempre según él- otro tanto le sucedió a Mateo Gil, a quien Piñeyro había conocido a través del actor español Eduardo Noriega, uno de los protagonistas de Plata quemada. Inmediatamente consiguió productor en España pero, para tratar de asegurarse una mayor repercusión en el viejo nuevo mundo, “...cuando tenía todo armado y el guión casi listo, me di cuenta que iba a hacer una película de difícil estreno en Argentina. Y medio me desesperé”, confiesa Piñeyro. "Ahí se me ocurrió que había un papel perfecto para Pablo Echarri, si lo cambiábamos un poco. Y lo llamé, sin saber si tenía tiempo ni nada. No tenía una segunda opción. Pero me dije: si puede, armo una coproducción y listo; y si no, era que no tenía que ser. Fue como tirar los dados. Por suerte, Pablo me dijo que sí, sin siquiera leer el guión. Y a partir de ahí se hizo la última reescritura, con un argentino entre los aspirantes”. Finalmente, las productoras acreditadas fueron Tornasol y Alquimia (por España), Arena (por Francia) y Cattleya (por Italia), lo cual conlleva que la consideración de la cinta como argentina no responde a razones administrativas, sino culturales y personales. 
Agustín Rubio Alcover, Sin lugar en el mundo. Narrativa, puesta en escena y discurso en las películas hispanoargentinas de Marcelo Piñeyro

La relectura cinematográfica de Piñeyro y Gil no convenció al comediógrafo, quien, no obstante, se abstuvo de decirlo públicamente hasta mucho después. En El Cultural de El Mundo, el autor de la obra original reconocía que escribió El método Grönholm tras cinco años de parálisis creativa debido al éxito de Dakota y Palabras encadenadas en 1995 (esta última llevada al cine por Laura Mañá en 2003). A propósito de las diferencias entre su obra y la película, y a modo de valoración personal, añadió: "El método Grönholm la escribí como comedia, pero en su adaptación al cine se convirtió en drama, y ya no me gustó" (Perales, 2013, p. 34).

No obstante, El Método obtendría dos Goyas, al mejor actor de reparto (Carmelo Gómez) y al mejor guión adaptado. Y, lo que es más importante, sirvió al cineasta para consolidarse en la industria española. Más que como comedia, cabría definir El método Grönholm como una farsa. En la adaptación, según propia declaración los referentes fílmicos que se manejaron fueron 12 hombres sin piedad (Twelve Angry Men, Sydney Lumet, 1957), La chinoise (Jean-Luc Godard, 1967) y Danzad, danzad, malditos (Sidney Pollack, 1969) (López Pérez, 2010). El plantel de personajes se amplía de cuatro aspirantes al puesto de alto ejecutivo de la multinacional a siete, más una secretaria a quien interpreta la también hispanoargentina Natalia Verbeke -significativamente, es el papel del topo de la empresa el que interpreta el otro intérprete sudamericano de la película, Pablo Echarri, lo cual construye, paratextualmente, un ambiguo discurso acerca de las relaciones de poder en la era de la globalización.

La estructura es casi idéntica a la de la obra teatral, aunque está más desarrollada y: el arranque con el desayuno de los candidatos en sus respectivos hogares; la presentación de todos ellos frente a los demás como primer ejercicio, de autodefinición (por sus trabajos anteriores, cargas familiares, etcétera); los cada vez más perversos y retorcidos juegos de rol para descartar candidatos; la revelación de secretos; las alianzas coyunturales por intereses compartidos y las posteriores traiciones, como daños colaterales... A diferencia de lo que sucede en el original de Galceran, al final los dos únicos candidatos que quedan son los que ya se conocían 
Agustín Rubio Alcover, Sin lugar en el mundo. Narrativa, puesta en escena y discurso en las películas hispanoargentinas de Marcelo Piñeyro

antes y habían tenido un affair (Carlos y Nieves), lo cual potencia el componente de competitividad caiga quien caiga, por encima de cualquier otro valor (la empatía, la atracción).

La puesta en escena constituye un auténtico tratado de supeditación a un texto y a unos intérpretes -muy retocado, eso sí, con respecto a El método Grönholm: El método es, en cierto modo, teatro filmado; pero, como en otras (buenas) películas con las que comparte esa condición, el calificativo modifica al sustantivo. Así, el tiro de cámara en relación a los sujetos (de uno en uno o varios), la posición (frontal, de espaldas o en escorzo; la angulación con respecto a ellos...), etcétera, comentan sutilmente y resultan imprescindibles para comprender lo que está sucediendo, pues lo que los personajes dicen en voz alta no solo no siempre se corresponde con lo que piensan o pretenden, sino que a menudo es radicalmente opuesto.

La coincidencia de la acción con una conferencia internacional durante la cual se organiza una protesta antiglobalización que se salda con una batalla campal sirve para mucho más que dibujar un telón de fondo: los personajes ven la televisión u oyen la radio (a través del reloj-despertador) durante el desayuno; y, como en los planos capturados [figs. 55-56], la pantalla partida sirve tanto para mostrar la fragmentación social y la soledad de los individuos, arrinconados por el temor, en sus propias casas, como para ilustrar la simultaneidad de actos idénticos, y su común preocupación por las mismas cuestiones. Luego, la manifestación es contemplada desde la sala donde se lleva a cabo la selección aplicando el método Grönholm, escenario apocalíptico en el desenlace [fig. 57].

Los recesos en el baño también sirven para desarrollar la psicología de los personajes, complicar las relaciones que entre ellos se establecen (el sexo casual para atar al otro...), airear el largometraje (de casi el doble de duración que la pieza escénica) sacándolo de la sala de juntas, y, por último, reflejar ciertas situaciones muy caras a Piñeyro (por ejemplo, el dualismo camaradería-rivalidad masculina, con tres de los personajes haciendo chistes sobre el acto fisiológico de orinar en un plano que, al cabo, se revela como el reflejo en el espejo del baño) [figs.58-6o]. La similitud de la construcción de 156 
Agustín Rubio Alcover, Sin lugar en el mundo. Narrativa, puesta en escena y discurso en las películas hispanoargentinas de Marcelo Piñeyro

los planos frente al espejo y tras el ventanal refuerza las ideas de encierro y escisión de los personajes, entre la identificación con quienes protestan fuera, la propia afirmación a través de una construcción ideal basada en la pura apariencia opuesta a la de los excluidos, y el miedo que los estimula a luchar entre sí para meter cabeza en el bando contrario.

\section{Envasar el vacío: Las viudas de los jueves}

Claudia Piñeiro (con i latina y sin ningún parentesco con nuestro director, nacida en Burzaco en 1960), que en 2005 (fecha de publicación de Las viudas de los jueves) apenas contaba con la experiencia de un par de novelas infantiles editadas y otra policiaca casi simultánea (Tuya, 2005), obtuvo gracias a esta obra el reconocimiento inmediato. Gerardo Herrero adquirió los derechos de adaptación, que sacaría adelante con sus productoras Tornasol, Haddock y Castafiore, más el canal argentino Televisión Federal (Telefe), y ofreció a Marcelo Piñeyro dirigirla. Según confesaría el realizador a López Pérez (2010), el productor tuvo que insistir mucho para vencer los prejuicios que tenía no ya para aceptar el encargo, sino siquiera para leerla. Eso sí, cuando al final se decidió -aprovechando otro vuelo, como en Plata quemada-, cambió de opinión de inmediato. Fue Piñeyro quien contactó con su coguionista habitual, y la historia de El Método se repitió casi punto por punto. Quizás por ello la autora se mostró solo diplomática al valorar el resultado: "Antes de comenzar a trabajar sobre la novela, Piñeyro y Figueras se reunieron con Piñeiro. Le contaron el proyecto, qué querían incluir, qué dejar afuera. Ella lo tomó como una reunión de cortesía: 'La película tiene muchas cosas distintas a la novela, pero me parece que eso debe ser una película: es la mirada del director sobre tu texto, porque si no el director es un empleado tuyo. El es un artista que hace su proyecto basándose en tu texto"” (PZ, 2010).

A priori, Las viudas de los jueves pudiera parecer un mero exploit de Las vírgenes suicidas (The Virgin Suicides, la adaptación de Sofia Coppola de la novela de Jeffrey Eugenides, 1999) y de la aplaudida serie estadounidense 
Agustín Rubio Alcover, Sin lugar en el mundo. Narrativa, puesta en escena y discurso en las películas hispanoargentinas de Marcelo Piñeyro

Mujeres desesperadas (Desperate Housewives, 2004). En la entrevista con Matías Orta (2010), Piñeyro reconocería otra posible influencia, involuntaria en este caso, del novelista John Cheever y de la adaptación de su novela $E l$ nadador (The Swimmer, Frank Perry, 1968), una de las favoritas tanto de Figueras como suya. Con todo, en una entrevista para la plataforma filmin con motivo del estreno en España de Las viudas de los jueves (Anónimo, 2010), Piñeyro se declaraba intuitivo, aunque reconocía ser consciente de que había un hilo de continuidad con respecto a El método al menos en dos aspectos: la voluntad de reflejar la reacción de una misma clase social en el actual momento histórico, y el hecho de que las dos tramas transcurran en entornos muy cerrados, si bien en un caso se trata de la oficina de una empresa multinacional (es decir, laboral) y en el otro de un barrio residencial (esto es, privado).

La película ahonda en la disyuntiva a que se enfrenta el hombre contemporáneo: conformarse con ser explotado -y ser deshumanizado, reducido a la condición de mercancía- o rebelarse como explotador y devenir mercader. Por lo general, el tono del film es bajo, lejos del poder de evocación de la novela de Claudia Piñeiro, quien, con una trama reducida a la mínima expresión, y a través de escenas cortas a menudo estrictamente caracterizadoras del ambiente, las relaciones y la mentalidad de la urbanización de lujo de Altos de la Cascada, traza un retrato inmisericorde de una clase en proceso de descomposición. No obstante, la adaptación de Marcelo Piñeyro se redime gracias a un par de situaciones e ideas.

El arranque tiene lugar con un gesto característico: el encendido de un cigarrillo por parte de un personaje mientras conduce, en un plano medio corto frontal a través del parabrisas [fig. 61]. Su entrada en la urbanización de lujo en la que se desarrolla la acción, puntillosamente situada por un rótulo la "madrugada del 17 de diciembre de 2001", y supondrá el comienzo de un relato claustrofóbico - de ahí el cartelón en la verja de acceso que declara "Prohibido el acceso a personas ajenas al country" [fig. 62], reminiscencia del mítico No Trespassing inaugural de Ciudadano Kane (Citizen Kane, Orson Welles, 1941). 
Agustín Rubio Alcover, Sin lugar en el mundo. Narrativa, puesta en escena y discurso en las películas hispanoargentinas de Marcelo Piñeyro

La salida de cuadro del personaje femenino del porche junto a la piscina en la que yace su marido y las otras dos víctimas, y el tilt descendente que muestra los cadáveres sumergidos en el agua, de un azul intenso [figs. 63-64] -que dice mediante imágenes que lo que hay la piscina es el reverso oculto, profundo de la plácida superficie-; da paso a los créditos, en los que se suceden planos de los difuntos, inertes pero con cuerpos casi perfectos y las facciones relajadas: planos estatuarios de, por fin, seres ideales, como conservados en formol [fig. 65] -particularmente bello, intencionado y coherente el último plano de la escena, que muestra, en continuidad, a los tres amigos juntos, con los ojos abiertos y una expresión que se antoja atónita; plano, significativamente, que se evita "manchar" con la incrustación de ningún crédito [figs. 66-68]. Es así como la película conjuga cinematográficamente algo que está muy presente en la novela: el final de la New Age, ese simulacro que prometía a los sujetos una bienestar eterno, una edad sin edad en un limbo del que la pobreza y las diferencias de estatus, la enfermedad y los estragos del tiempo estaban evacuados -no superados sino latentes, por excluidos del horizonte de lo visible; ergo seguían rigiendo como amenazas, por el temor a ser arrojados a las tinieblas exteriores. Esas imágenes, por cierto, invitan a ser leídas en relación directa con las del embalsamamiento del Tano, durante la cual la radio que oye la maquilladora anuncia la medida gubernamental de la congelación de los depósitos bancarios, de manera que "ninguna persona podrá extraer de su cuenta más de 300 pesos o dólares semanales" [figs. 69-70].

A partir de ese instante, se suceden monólogos definitorios de una clase en trance de disolución por el advenimiento del desastre del corralito. Estos monólogos (como el que sigue, que El Tano pronuncia en su primera comparecencia vivo frente a la cámara: "Cuando era chico creía en Dios: decían que nunca me iba a decepcionar, pero cuando lo necesité no estuvo. Después creí en la democracia: creí que era la solución a todos los desvelos; con la democracia se come, se cura, se educa... ¿̇Te acordás? ¿Sabés en lo que creo ahora? En la guita; el verdadero idioma internacional. Con plata el bolsillo, te entienden en todas partes. Si le tenés fe, la guita aparece. Siempre. 
Agustín Rubio Alcover, Sin lugar en el mundo. Narrativa, puesta en escena y discurso en las películas hispanoargentinas de Marcelo Piñeyro

En cambio, Dios...”) no proceden de la novela, sino que son de la cosecha de Figueras y Piñeyro, y, si bien son comprensibles debido a la necesidad de formular de manera expresa ideas que en el más enigmático, elegante original quedan implícitas, alejan el film de la cualidad hipnótica de su referente literario y lo dotan de un tono algo panfletario.

La dialéctica rivalidad/camaradería masculina se concreta, entre otras situaciones, en un aspecto presente en la novela, plenamente desarrollado por parte de Claudia Piñeiro: la importancia que el tenis tiene en la forja de la relación triangular entre El Tano, Ronie (su compañero tradicional en las partidas de dobles, con el que forma una pareja imbatible) y Gustavo Massota (un jugador semiprofesional que, nada más llegar, reemplaza a Ronie y se convierte en el complemento de quien en las presentaciones es descrito como "el rey sin corona de este lugar"). El cruce de miradas entre Gustavo (que maltrata a su mujer) y El Tano (cuya esposa siente una atracción lésbica por la mujer de Gustavo, y se declara), entre el desafío y la seducción, tan parecido al de El Nene y Ángel en Plata quemada, sugiere la confusa naturaleza de la conexión que establecen a primera vista [figs. 71-73]. Particular importancia tienen las escenas junto a las piscinas, símbolo de estatus y de confort, recordatorio del arranque (y hacia el que fatalmente progresa el relato). No faltan los planos, compartimentados y subdivididos en la tercera dimensión en espacios distintos e impenetrables en función de su estatus, que muestran a los personajes privilegiados en las celdas de seguridad en que convierten esas mansiones, en las que nunca falta la pileta [figs. 74-75]. Ni siquiera falta el momento en que los varones orinan codo con codo, en este caso en el jardín -una transgresión liberadora, que les produce una satisfacción instintiva y les incita a bromear, competir y humillarse en tanto que machos: de ahí que El Tano palmee a Martín sin haberse lavado las manos ("Desconfiá del tipo que te da consejos con la pija en la mano" [fig. 76-77]. También junto a la piscina Ronie elogia que aquél invierta en el negocio de la beaticación, esto es, comprando los seguros de vida de moribundos ("Sublime, Tano, es sublime. De verdad, es sublime cómo desnudás la naturaleza del sistema que es predatorio, por supuesto. Es 
Agustín Rubio Alcover, Sin lugar en el mundo. Narrativa, puesta en escena y discurso en las películas hispanoargentinas de Marcelo Piñeyro

capitalismo puro", le espeta, sarcástico. "Nadie sobrevive sin culpa, Ronie. Es el precio a pagar. ¿Y querés que te diga algo? No me parece tan alto”, replica el otro) [fig. 78 ].

En la escena en que El Tano propone a sus amigos suicidarse juntos para que sus familias cobren el seguro "y arrancarle algo a esa muerte", solo comparten plano en el momento en que él, señalando la piscina, especula con la posibilidad de que, estando los cuatro dentro, el equipo de música cayera por accidente y se electrocutasen [fig. 79]. El resto consiste en una rigurosa concatenación de primeros planos de cada uno por su cuenta. “...existe la posibilidad de llegar a viejos. Seguir adelante hasta que los cuerpos no den más. Pero ahí ya no queda lugar para política alguna. Ahí todo duele demasiado, todo pesa demasiado. Ahí ya no queda nada para negociar. A esa altura lo único que queda es rendirse”. Tano aduce razones sociopolíticas (“...entendí que mi bienestar está basado en el malestar de otros. El sistema funciona así, vos sabés, y ya no quiero joder a nadie”), sentimentales (“amo a alguien que no me corresponde"), filosóficas ("quiero escapar de una verdad que no tolero") o existenciales ("estoy cansado"). El discurso que invoca Leonardo Sbaraglia para justificar su renuncia al suicidio en Las viudas de los jueves ("Yo sé que soy una carga para Mavi [...] Matarme sería negar todo eso otro que también soy, una manera de denigrarla, de decirle que solo me veía como un proveedor [...] Además está mi hijo. Yo sé que es un desconocido para mí. ¿Por qué uno tiene que querer solo lo que conoce? Estamos solos como perros, pero en esa soledad encontrarme con mi hijo es un milagro. Por eso quiero estar cerca de él, porque es en lo primero que pienso al levantarme en la mañana”) remite al discurso acerca del potencial parcialmente redentor de la paternidad. Solo cuando Ronie se levanta, anuncia su marcha y trata de retener al resto, pero Tano consigue convencer sin palabras a Gustavo y a Martín para quedarse, se rompe esa tónica, y aparecen dos personajes juntos: el que decide vivir, de pie, en segundo término y con rostro serio, buscando con los ojos puestos en el fuera de campo a los otros dos para persuadirlos; el que está resuelto a morir y 
arrastrar a los demás con él, sentado, fumando, sonriendo y manteniendo quietos a sus interlocutores gracias a la fijeza de su mirada [fig. 80].

Hay, pues, dos salidas posibles; literalmente: morir (y así no salir del country, ni siquiera con los pies por delante) o marchar. Es en mitad del relato cuando, por primera vez, la cámara sale del country, siguiendo los pasos de la hija rebelde de los Urovich [fig. 81]. Ese gesto marca el punto medio, se proyecta y anuncia el desenlace, con la marcha de la familia de Ronie y de la joven (novia del hijo de los Guevara), la tarde de la jornada en que estallan los disturbios. Ronie contempla los altercados en la televisión [figs. 82-83]. A pesar de saber estar al tanto, ellos deciden abandonar Altos de la Cascada e internarse en la jungla del mundo real. Planos subjetivos a través de la luna posterior del todoterreno captan las calles (vacías, por supuesto) del suburbio, hasta que cruzan la verja se pierden de vista [figs. 84-85].

Las viudas de los jueves se estrenó en Argentina el 10 de septiembre de 2009 -esto es, la víspera del octavo aniversario de la caída de las Torres Gemelas-, mientras que en España hubo de esperar más de seis meses, hasta el 26 de marzo del año siguiente. Clarín, cuya edición estaba dedicada casi en su totalidad a la enésima batalla en la guerra que había supuesto la promulgación de una Ley de Medios por parte del gobierno kirchnerista que perjudicaba al grupo mediático al que pertenecía el periódico, saludó el estreno de la película ("Las viudas de los jueves: ascenso y caída del country"), adaptación de la novela que se había alzado con el premio del periódico en la edición de 2005. La reseña de Miguel Frías, tibiamente positiva, aplaudía sobre todo a los intérpretes, si bien no se abstenía de señalar que "No convencen, en cambio, ciertos subrayados retóricos, prescindibles, que no le aportan solidez al relato: al contrario”. En España, las palabras de Herrero resultaron proféticas, y el film pasó sin pena ni gloria. 
Agustín Rubio Alcover, Sin lugar en el mundo. Narrativa, puesta en escena y discurso en las películas hispanoargentinas de Marcelo Piñeyro

\section{Coda: “¿Crisis? ¿Cuál crisis?”}

Un cineasta habla a través de la puesta en escena; esto es, de la gestión de los cuerpos en el espacio y el tiempo fílmicos. Las cuatro películas hispanoargentinas de Marcelo Piñeyro muestran personajes (hombres y mujeres que se relacionan promiscuamente, no solo en un sentido sexual) encerrados, fugitivos en unos casos (perseguidos la justicia o por el rival político: una dictadura militar), aspirantes a un puesto de trabajo, o privilegiados en su propia burbuja. También paradójicamente, todos ellos contribuyen a su propio aislamiento -como estrategia de salvación, por miedo, por ambición, por un concepto perverso de la dialéctica entre ricos y pobres. Se diría que lo que más interesa a Piñeyro son las relaciones de dependencia y dominación que se forjan en el seno de la familia, el trabajo y la pareja (heterosexual y normativa u homosexual -gay o lésbica- y prohibida, según el reparto inicial), en particular cuando se confunden, se trastocan y las convenciones, más que en cuestión, quedan dinamitadas. En su poética, los motivos del agua y el fuego, como emblemas o augurios del ahogamiento y sofocación; la disyuntiva entre los paisajes natural y humano; y la dialéctica cromática entre tonos fríos (azules) y cálidos, simbolizan y aceleran el enrarecimiento o la suspensión del tiempo.

No menos elocuente resulta que estos relatos sobre seres varados sean producto de coproducciones hispanoargentinas, en las que los referentes (y los intérpretes) sean sometidos a un proceso consciente de acomodación a los dos países empeñados en ellas. En todos los casos, puede hablarse de una delicada y personal reinterpretación internacionalista, como resultado del proceso de adaptación de novelas originales (salvo en un caso, en que se invierten las tornas y la versión literaria es la derivativa), siempre más uniformemente vernáculas. La demostración de que, a través de una pirueta paratextual, Piñeyro naturaliza esa interferencia de los condicionamientos de orden productivo, convierte la indagación en la crucial dimensión del espacio (la escala del plano y los cuerpos que eventualmente la ocupan, el juego con la profundidad de campo, si es abierto o cerrado, reconocible y culturalmente marcado o más abstraído y desreferencializado, de época o 163 
contemporáneo...) en algo más que una simple manía personal o un juego vacuo. Se trata, por el contrario, de uno de los instrumentos a que recurre sistemáticamente el cineasta para crear sentido, en la más amplia y noble acepción de la expresión; pero también señala los límites del rango de posibilidades de un cineasta actual y al que podemos llamar nuestro, que no renuncia ni a trabajar según una lógica industrial ni a hacer una crítica genuina y profunda de las lacras de la sociedad en que vivimos, con un pie a cada lado del océano... y sin naufragar en el intento.

\section{Referencias bibliográficas}

Anónimo (2010). Entrevista con Marcelo Piñeyro (https://www.filmin.es/blog/entrevista-a-marcelo-pineyro-directorde-las-viudas-de-los-jueves)

Anónimo (s.f. a). Entrevista con Aida Bortnik (http://www.conectate.gov.ar/module/detalleRecurso/DetalleRecurso .do?modulo=etiquetas\&tipoEmisionId $=3$ \&etiquetaId $=41558$ \&etiqueta $\underline{\text { Desc }}=$ literatura\&recursoPadreId $=101920 \& i d R e c u r s o=108922$

Anónimo (s.f. b). Marcelo Piñeyro: "Plata quemada me eligió a mí" (http://www.terra.com.ar/canales/cine/o/201.html)

Campodónico, R. H. (2010). Informes y testimonios: La representación de las luchas y reivindicaciones sociales en el cine sonoro argentino (19332003). En Campodónico, R. H. (Comp.) (2010). El cine cuenta nuestra historia. 200 años de historia, 100 años de cine (364-427). Buenos Aires: Instituto Nacional de Cine y Artes Audiovisuales.

Campodónico, R. H. (Comp.) (2010). El cine cuenta nuestra historia. 200 años de historia, 100 años de cine. Buenos Aires: Instituto Nacional de Cine y Artes Audiovisuales.

Elena, A. (2011). Difusión y circulación del cine argentino en España. En VV.AA., Imágenes compartidas. Cine argentino-cine español (pp. 2949). Buenos Aires: CCEBA Apuntes.

Figueras, M. (2004). Kamchatka. Madrid: Suma de Letras.

Galceran, J. (2006). El método Grönholm. Madrid: SGAE.

Herrero, G. (abril de 1995): Tan lejos y tan cerca. En Academia. Revista del cine español: "Latinoamérica, años 90" (pp. 84-87). Madrid: Academia de Cine.

Kohen, H. (2010). El espectáculo en el cine argentino. En Campodónico, R. H. (Comp.) (2010). El cine cuenta nuestra historia. 200 años de 
historia, 100 años de cine (pp. 310-337). Buenos Aires: Instituto Nacional de Cine y Artes Audiovisuales.

Lara, F. (2011). Nada sería igual sin Ibermedia. En VV.AA., Imágenes compartidas. Cine argentino-cine español (pp. 272-287). Buenos Aires: CCEBA Apuntes.

López Pérez, J. (2010). Entrevista a Marcelo Piñeyro, director de Las viudas de los jueves (http://www.elblogdecineespanol.com/?p=1348)

Orta, M. (2010). Entrevista con Marcelo Piñeyro (http://www.asalallenaonline.com.ar/entrevistas/51-directores/167entrevista-a-marcelo-pineyro.html)

Perales, L. (15 de noviembre de 2013). Jordi Galceran: "No soy Shakespeare pero sé en qué liga juego". En El Cultural de El Mundo (pp. 32-34).

Pérez, M. (2005). $\quad$ El elegido (http://www.pagina12.com.ar/diario/suplementos/radar/9-28652006-03-12.html)

Piglia, R. (2013). Plata quemada. Barcelona: DeBolsillo.

Piñeiro, C. (2013). Las viudas de los jueves. Madrid: El País-Santillana.

PZ

(2010).

Entrevistas:

Piñeiro (http://blog.eternacadencia.com.ar/archives/2010/10013)

Quílez Esteve, L. (2012). Sutiles pasados. El cine documental y memoria en la Argentina de la postdictadura. Archivos de la Filmoteca, núm. 70 (pp. 85-91).

Consultado de http://www.archivosdelafilmoteca.com/index.php/archivos/article/vi ew/358

Rubio Alcover, A. (2013). Las cosas del comer. Nutrición e ideología en el cine contemporáneo (pp. 129-155). En Dossiers Feministes, núm. 17: Género, comida e identidad.

Soifer, A. (2009). Caja de resonancia (http://blog.eternacadencia.com.ar/archives/2009/3878\#)

Tolentino, J. (2005). Ni delfín, ni tiburón, ni morrajita. Diálogos con Leonardo Sbaraglia. Madrid: Ocho y Medio.

Vázquez Medel, M. A. (2008). Los rostros del horror y la mirada infantil: notas para una lectura de Kamchatka. En Comunicación, Vol.1, núm. 6 (pp. 46-55). ISSN 1989-600X (http://www.revistacomunicacion.org/pdf/n6/articulos/4_Los_rostr os_del_horror_y_la_mirada_infantil.pdf)

Yáñez, J. (2009). La alquimia de la creación. Madrid: Festival Internacional de Cine de Alcalá de Henares. 
Figs. 1-10
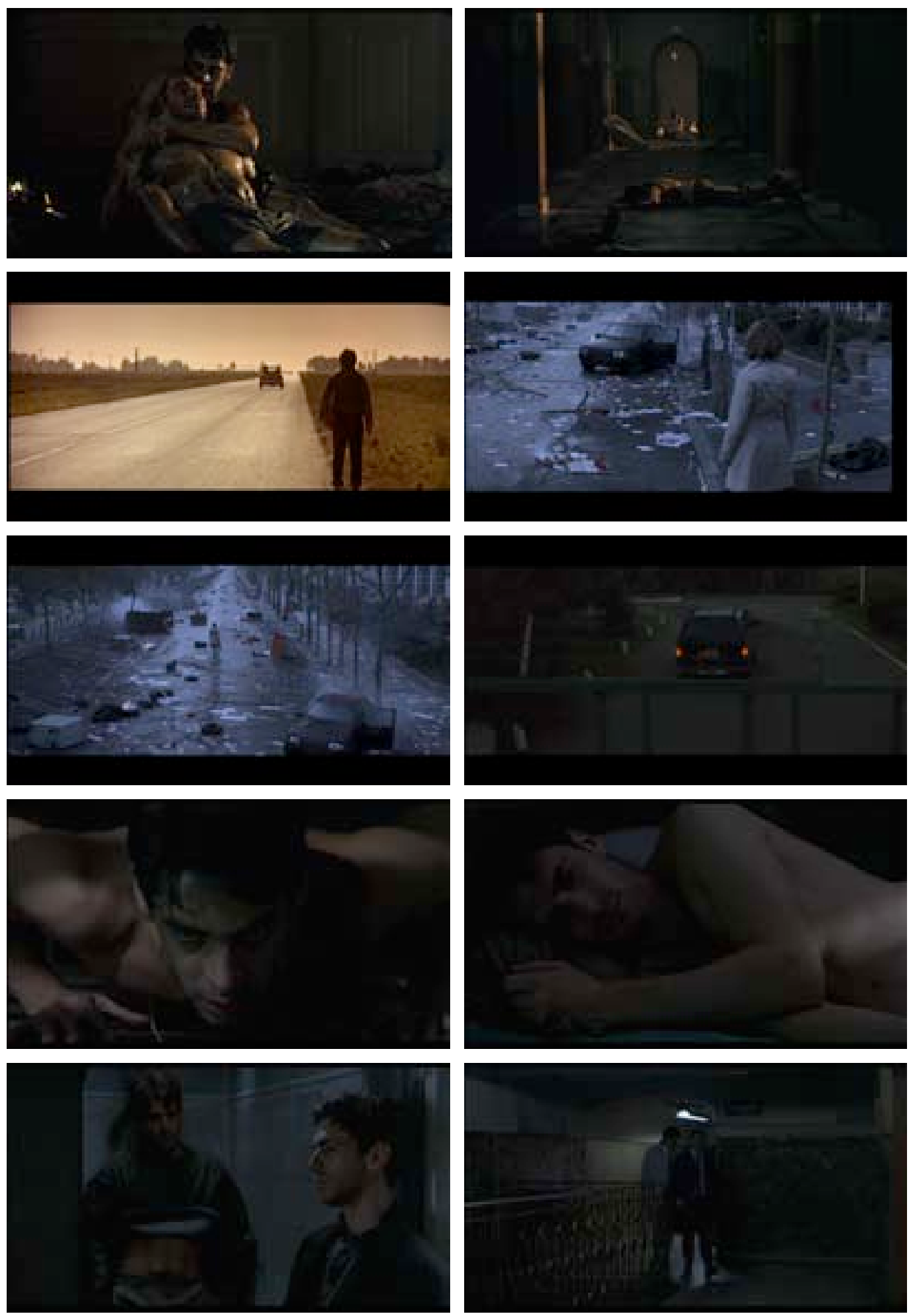
Agustín Rubio Alcover, Sin lugar en el mundo. Narrativa, puesta en escena y discurso en las películas hispanoargentinas de Marcelo Piñeyro

figs. 11-20
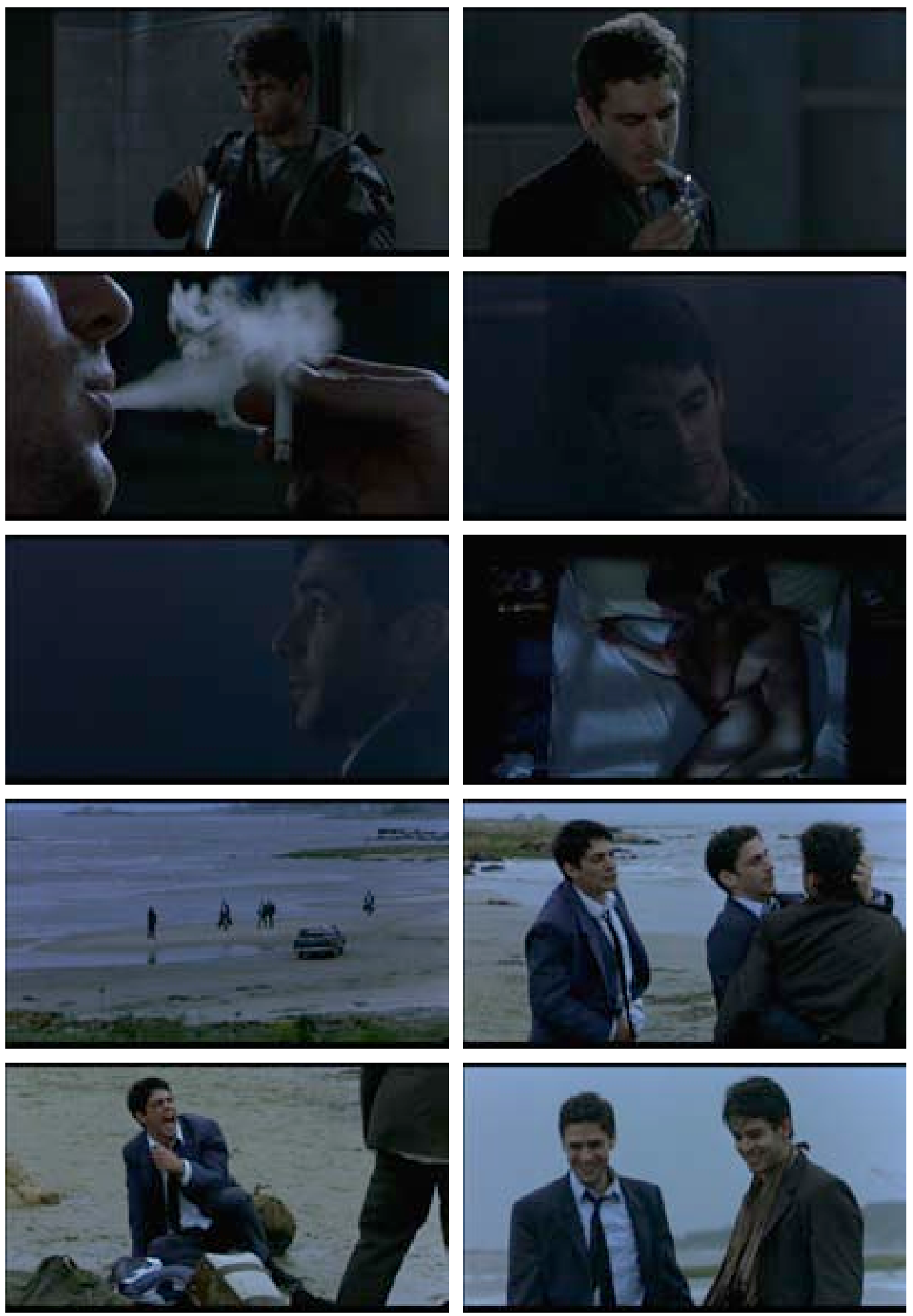
Agustín Rubio Alcover, Sin lugar en el mundo. Narrativa, puesta en escena y discurso en las películas hispanoargentinas de Marcelo Piñeyro

figs. 21-30
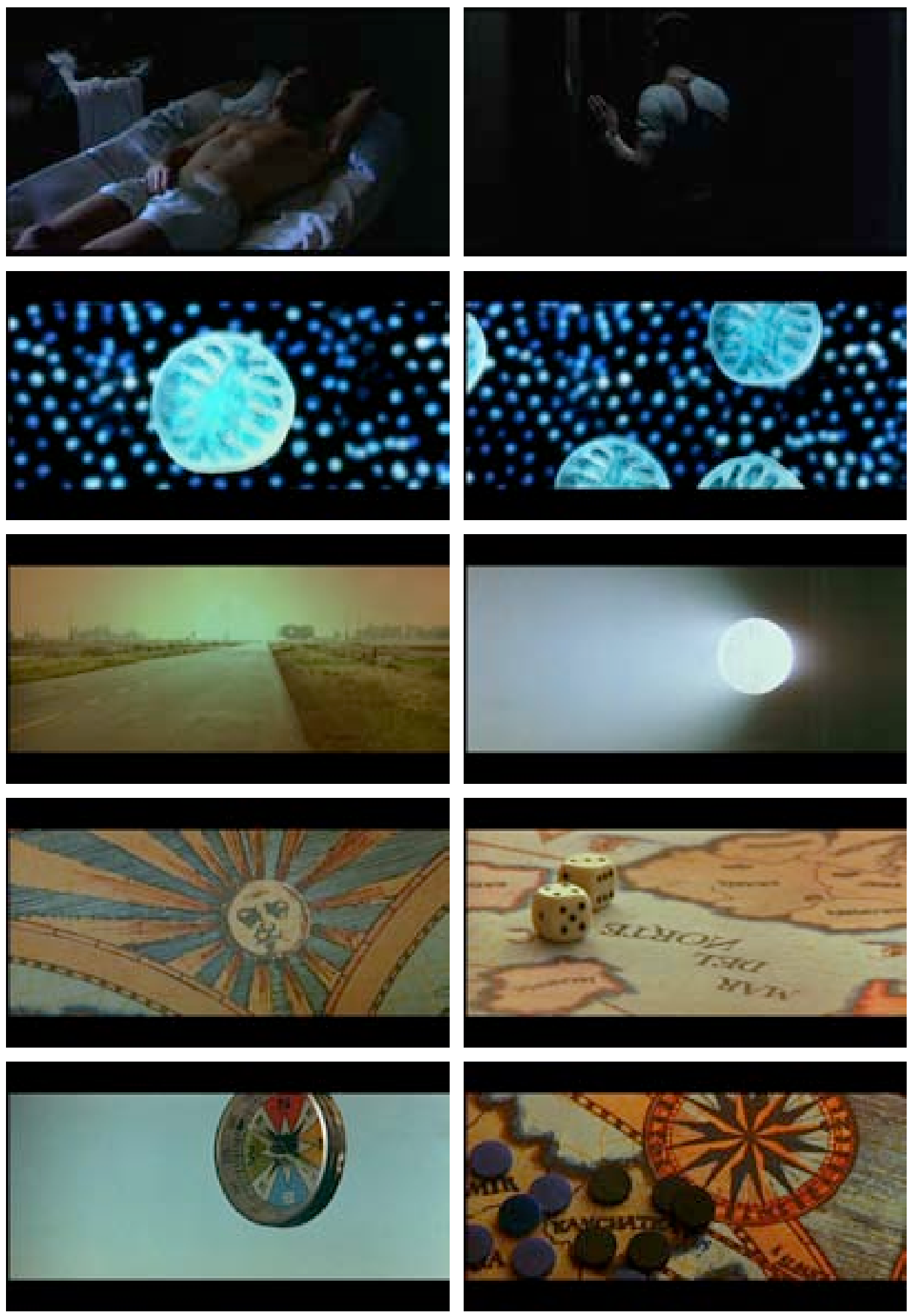
Agustín Rubio Alcover, Sin lugar en el mundo. Narrativa, puesta en escena y discurso en las películas hispanoargentinas de Marcelo Piñeyro

Figs. 31-40
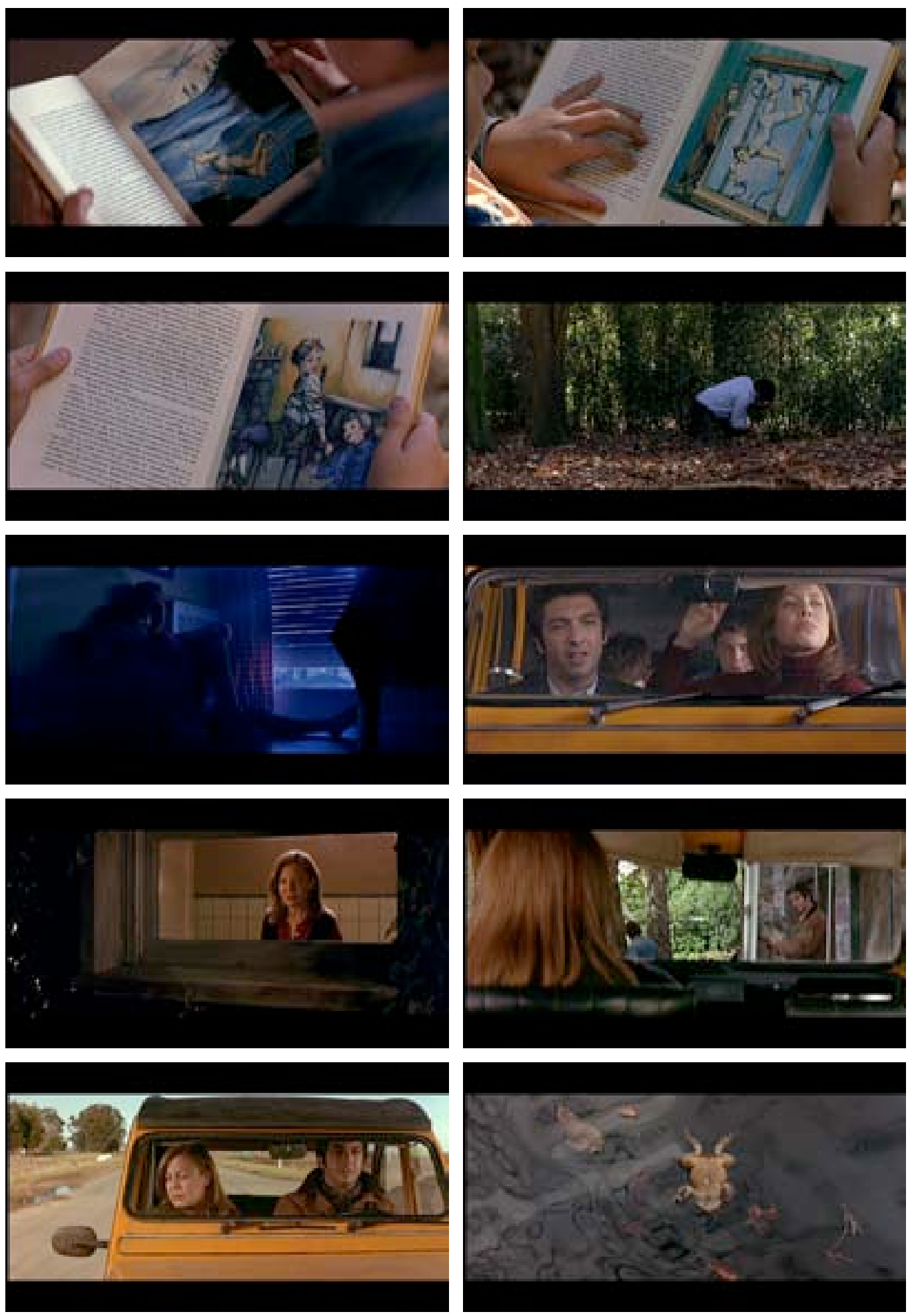
Fig. 41-50
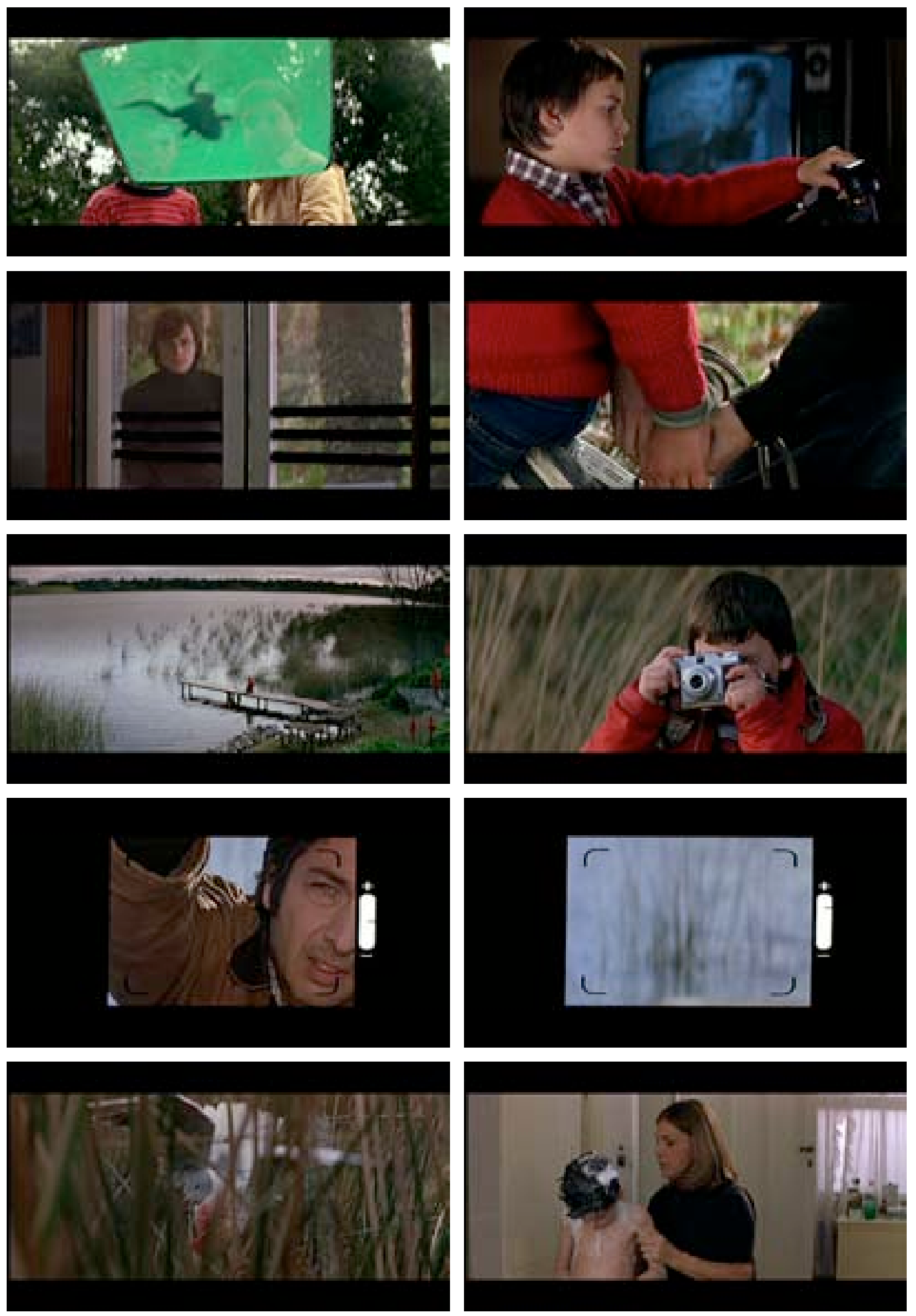
Agustín Rubio Alcover, Sin lugar en el mundo. Narrativa, puesta en escena y discurso en las películas hispanoargentinas de Marcelo Piñeyro

Fig. 51-60
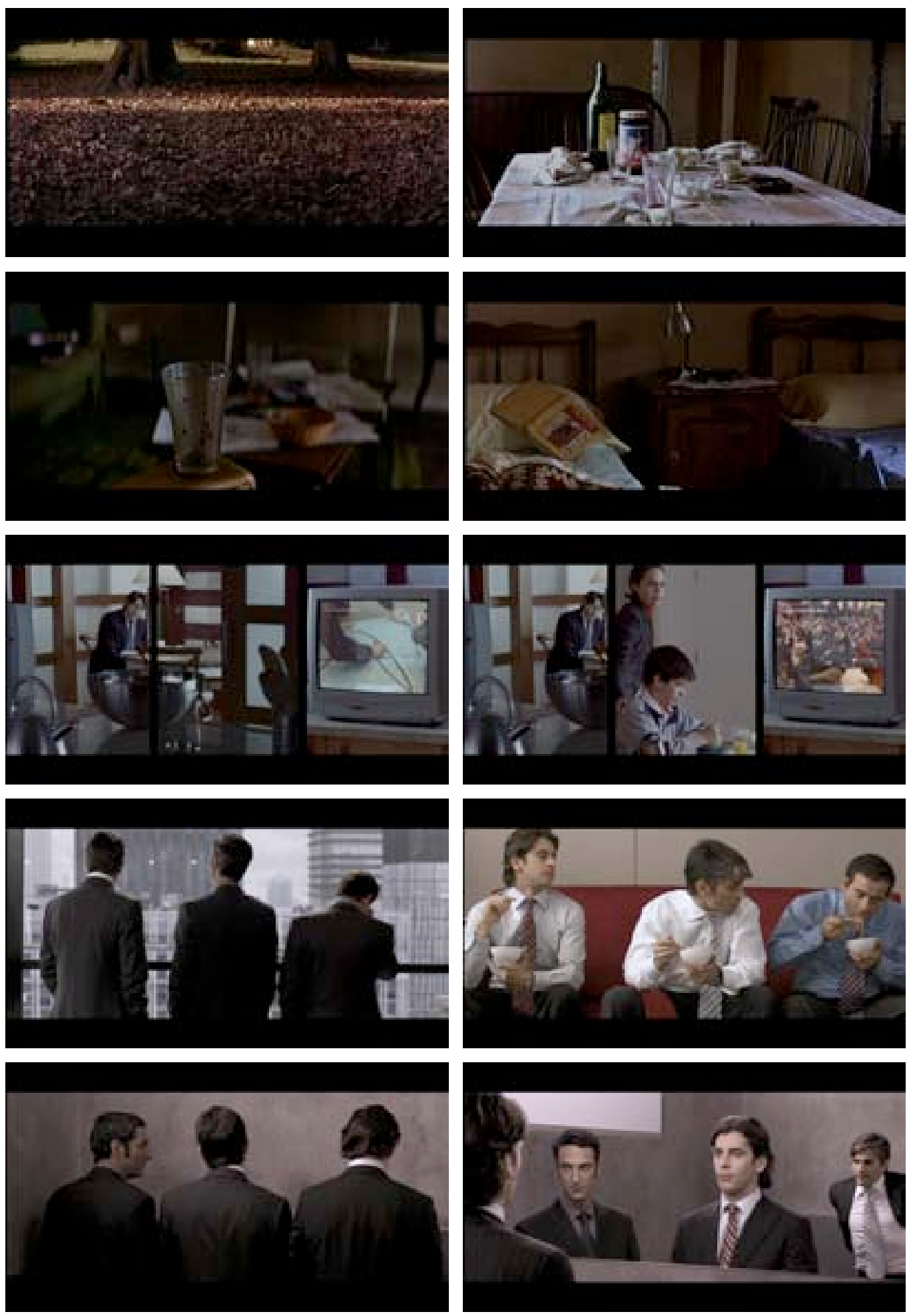
Agustín Rubio Alcover, Sin lugar en el mundo. Narrativa, puesta en escena y discurso en las películas hispanoargentinas de Marcelo Piñeyro

Figs. 61-70
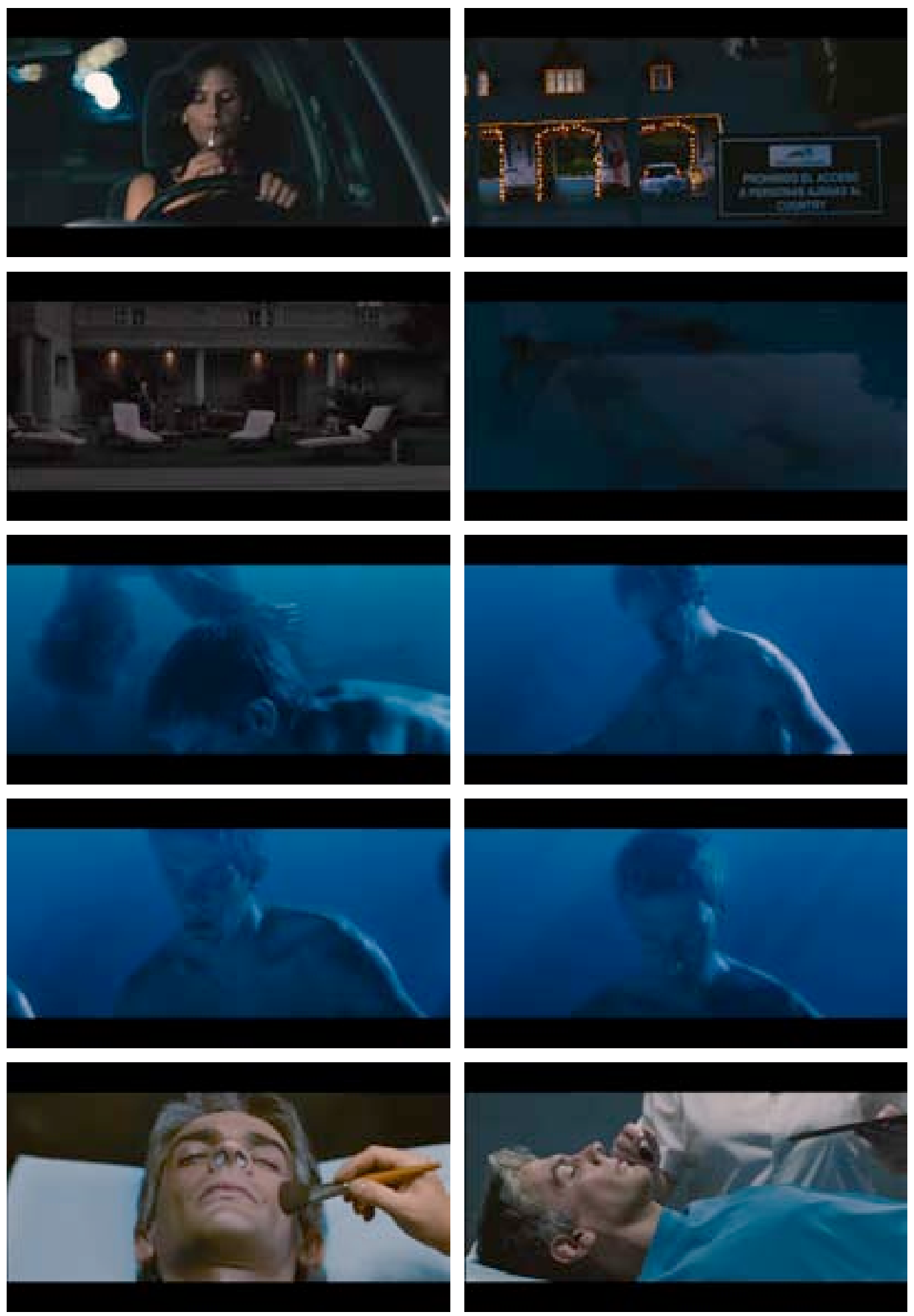
Agustín Rubio Alcover, Sin lugar en el mundo. Narrativa, puesta en escena y discurso en las películas hispanoargentinas de Marcelo Piñeyro

figs. 71-80
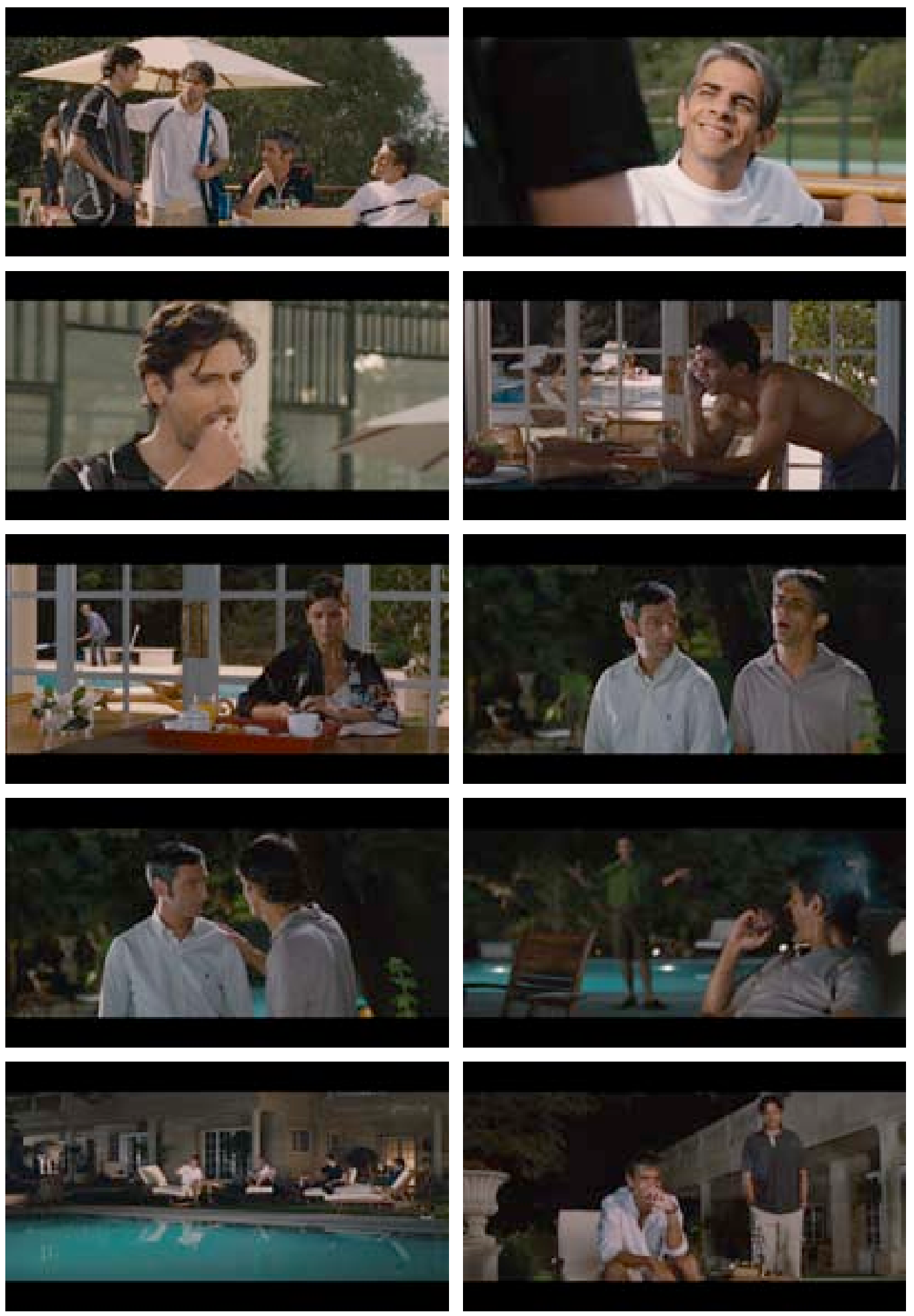
Agustín Rubio Alcover, Sin lugar en el mundo. Narrativa, puesta en escena y discurso en las películas hispanoargentinas de Marcelo Piñeyro

figs. $80-85$
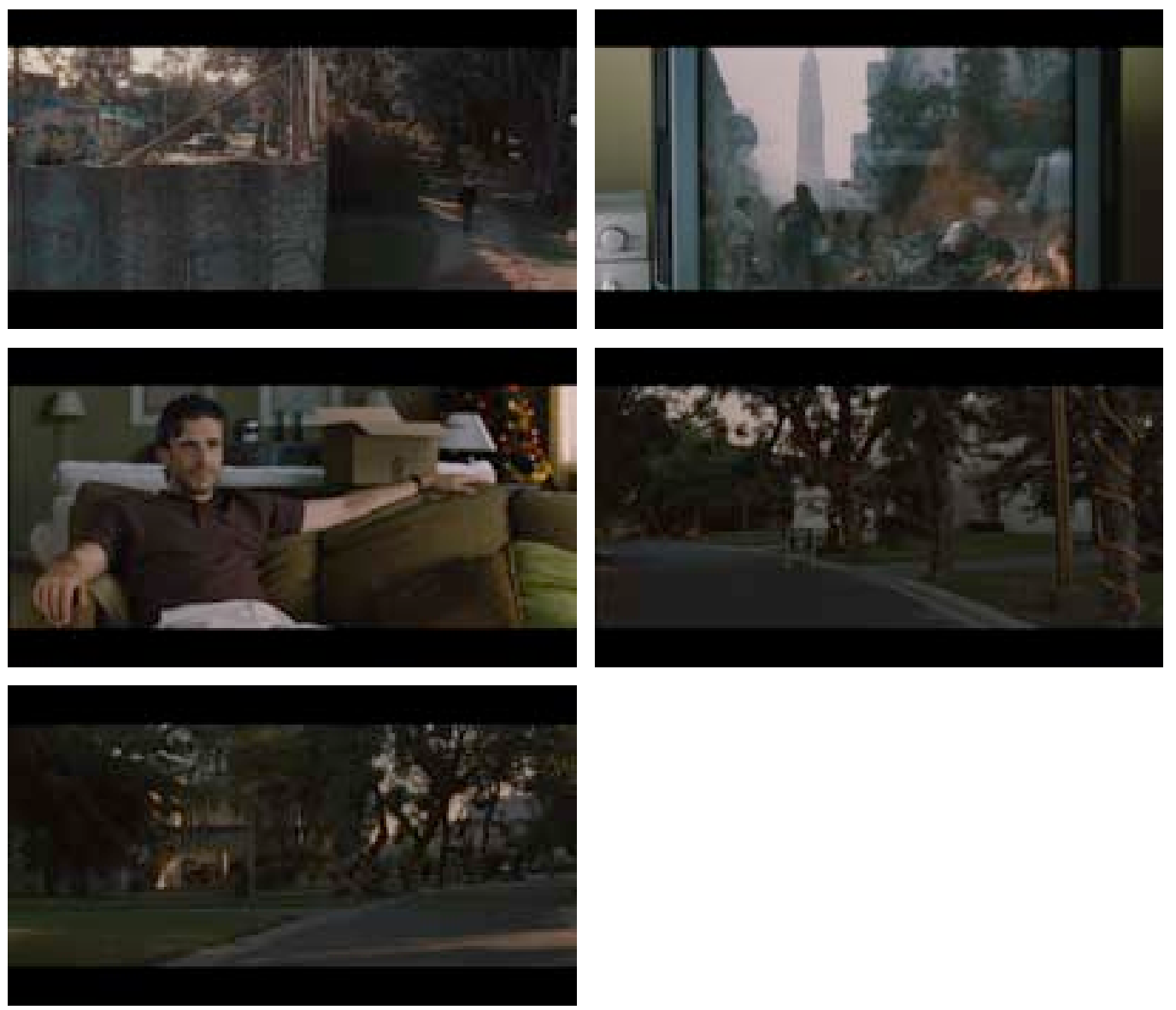